\title{
O gênero Paepalanthus Mart. (Eriocaulaceae) no Parque Estadual do Biribiri, Diamantina, Minas Gerais, Brasil
}

The genus Paepalanthus Mart. (Eriocaulaceae) at Biribiri State Park, Diamantina, Minas Gerais, Brazil

\author{
Caroline Oliveira Andrino ${ }^{1,3}$, Fabiane Nepomuceno Costa $^{2} \&$ Paulo Takeo Sano ${ }^{1}$
}

\begin{abstract}
Resumo
Paepalanthus Mart. (Eriocaulaceae) conta atualmente com cerca de 400 espécies, distribuídas principalmente nas Américas Central e do Sul, com centro de diversidade localizado na Cadeia do Espinhaço, em Minas Gerais e Bahia. É o gênero de Eriocaulaceae mais complexo do ponto de vista taxonômico e a carência de estudos florísticos dificulta o aprimoramento de sua circunscrição. Nesse contexto, foi efetuado o levantamento de Paepalanthus do Parque Estadual do Biribiri, que está inserido no Planalto de Diamantina, Minas Gerais. O gênero está representado no Parque por 33 espécies. É apresentada uma chave de identificação, descrições e ilustrações, bem como comentários sobre morfologia, habitat, distribuição geográfica e fenologia.
\end{abstract}

Palavras-chave: Campos rupestres, Cadeia do Espinhaço, endemismo, florística, Poales

\begin{abstract}
Paepalanthus Mart. comprises approximately 400 species, mainly distributed in South and Central America, with center of diversity located in the Espinhaço Range, in Minas Gerais and Bahia. In a taxonomic point of view, Paepalanthus is the most complex genus of Eriocaulaceae and the lack of floristic studies hinders the improvement of its circumscription. In this context, it was carried out the Paepalanthus flora of Biribiri State Park, which is located in Diamantina Plateau, in Minas Gerais state. In the area, the genus is represented by 33 species. Identification key, descriptions and illustrations, as well as comments about morphology, habitat, geographic distribution and phenology are presented.
\end{abstract}

Key words: rocky outcrops, Espinhaço Range, endemism, floristic, Poales.

\section{Introdução}

Eriocaulaceae possui distribuição pantropical e ocorre em diferentes habitats, mas a maioria das espécies está distribuída nos tepuis venezuelanos e nos campos rupestres brasileiros, especialmente na Cadeia do Espinhaço (Giulietti \& Hensold 1990; Costa et al. 2008). A família possui cerca de 1200 espécies, distribuídas em 10 gêneros (Giulietti et al. 2014) e pode ser reconhecida, dentre as monocotiledôneas, pela inflorescência capituliforme.

O gênero Paepalanthus Mart. conta atualmente com 426 espécies (Giulietti et al. 2014), distribuídas principalmente nas Américas Central e do Sul, com apenas cinco espécies na
África (Giulietti \& Hensold 1990). No Brasil, está representado por 337 espécies (Giulietti et al. 2014) estando entre os gêneros de angiospermas mais diversos do Brasil, juntamente com Eugenia L. (Myrtaceae) e Mimosa L. (Fabaceae), e, também, o que apresenta maior número de espécies endêmicas (Forzza et al. 2010). Possui ampla distribuição geográfica, ocorrendo em todas as regiões do país, com o principal centro de diversidade localizado na Cadeia do Espinhaço, onde se estima que ocorram cerca de 220 espécies (Costa et al. 2008). É reconhecido pelas flores estaminadas com pétalas unidas e pistiladas com pétalas livres, além de apêndices nectaríferos e estigmáticos liberando-se na mesma altura no gineceu, porém,

\footnotetext{
${ }^{1}$ Universidade de São Paulo, Instituto de Biociências, Depto. Botânica, Laboratório de Sistemática Vegetal, R. do Matão 277, Cidade Universitária, 05508-900, São Paulo, SP, Brasil.

${ }^{2}$ Universidade Federal dos Vales do Jequitinhonha e Mucuri, Depto Ciências Biológicas, Campus JK, Rod. BR-367, 39100-000, Diamantina, MG, Brasil.

${ }^{3}$ Autor para correspondência: carolineandrino@yahoo.com.br
} 
separadamente, estes caracteres são encontrados em outros gêneros da família.

Atualmente, um dos grandes problemas enfrentados no estudo de Paepalanthus consiste na falta de conhecimento acerca da morfologia e distribuição geográfica de boa parte das espécies. Estudos taxonômicos recentes, que tratam de espécies brasileiras do gênero, foram realizados em P. subg. Xeractis Mart. (Hensold 1988), P. subg. Platycaulon Mart. (Tissot-Squali 1997), P. sect. Diphyomene Ruhl. (Trovó \& Sano 2010), P. sect. Actinocephalus Koern (Sano 2004) e P. subsect. Aphorocaulon (Costa \& Sano 2013), sendo os dois últimos grupos transferidos para o gênero Actinocephalus. Na porção mineira da Cadeia do Espinhaço, os levantamentos florísticos abordando o gênero estão restritos à Serra do Cipó (Giulietti et al. 1987; Hensold 1998; Parra 1998; Sano 1998), Grão-Mogol (Sano et al. 2010) e parcialmente no Planalto de Diamantina (Andrino \& Costa 2013).

Nesse contexto, tendo-se em vista a elevada riqueza e diversidade de Paepalanthus na Cadeia do Espinhaço e a carência de levantamentos florísticos tratando do gênero como um todo, o presente estudo teve como objetivo efetuar o levantamento das espécies de Paepalanthus no Parque Estadual do Biribiri (Minas Gerais), no Planalto de Diamantina, um dos principais centros de diversidade do gênero. É apresentada uma chave de identificação, ilustrações, dados sobre fenologia, morfologia e distribuição geográfica das espécies.

\section{Material e Métodos}

O Parque Estadual do Biribiri (PEBI) (Fig. 1) possui 16.998,66 hectares e está situado na região do Alto Vale do rio Jequitinhonha, na porção central do Espinhaço mineiro, no sudeste do município de Diamantina. O Parque faz limites com à sede municipal e é delimitado ao sul/sudeste pela BR-367, no trecho entre Diamantina e Couto de Magalhães de Minas. As regiões leste e nordeste têm acesso a partir da comunidade de Mendanha, localizada junto à BR-367, às margens do rio Jequitinhonha.

O Parque é tradicionalmente dividido em pequenas regiões e essa setorização foi também adotada no presente estudo, são elas: Messias, Barris, Rocha, Caetano de Monteiro, São Miguel, Serra do Mendanha, Lapa do Forno, Alto do Jacuba, Água Limpa, Biribiri e Campo da Boa Vista (Fig. 1).
Totalmente incluído dentro domínio do bioma Cerrado, o PEBI possui diversas fisionomias de vegetação, associadas às diferentes condições do solo, de insolação, disponibilidade de água e microclima. Pode-se destacar, no Parque, a ocorrência de campos rupestres como uma fitofisionomia predominante. O relevo do PEBI é tipicamente acidentado, caracterizado por afloramentos rochosos quartzíticos, em altitudes que variam de 700 a 1400 metros de altitude (IEF 2004).

Foram realizadas expedições trimestrais para coleta de material entre outubro de 2010 e março de 2013, totalizando dez expedições. Todas as regiões do Parque foram percorridas e o material coletado foi georreferenciado, prensado, seco em estufa e, posteriormente montado em exsicatas, que foram depositadas no herbário da Universidade Federal dos Vales do Jequitinhonha e Mucuri (DIAM) e da Universidade de São Paulo (SPF). Também foram consultados os seguintes herbários: $\mathrm{BHCB}$, CEN, DIAM, MBM, OUPR, RB, R, SP, SPF, UB, UEC (acrônimos de acordo com Thiers 2014, continuamente atualizado).

Os espécimes foram examinados com auxílio de microscópio estereoscópico e identificados utilizando-se a última revisão do gênero (Ruhland 1903), além de revisões de taxa infragenéricos de Paepalanthus (Hensold 1988; Tissot-Squali 1997; Trovó 2010), espécies recém-descritas (Silveira 1908, 1928; Moldenke 1937, 1946, 1951, 1957, 1966, 1968, 1971, 1978), análise dos tipos nomenclaturais depositados em herbários nacionais e fotografias dos tipos das espécies que estão depositados em herbários estrangeiros. A terminologia utilizada para a descrição morfológica de estruturas vegetativas foi a proposta por Radford et al. (1974) e, reprodutivas, a de Weberling (1989), além da especifica da família (Rosa \& Scatena 2007, Scatena et al. 2008; Trovó 2010).

O mapa de distribuição geográfica das espécies na área de estudo (Fig. 1), inclui apenas os pontos cujos materiais examinados apresentavam coordenadas geográficas.

\section{Resultados e Discussão}

Foi registrada a ocorrência de 33 espécies de Paepalanthus para o Parque Estadual do Biribiri, sendo 26 espécies pertencentes a $P$. subg. Paepalanthus, 4 espécies a $P$. subg. Platycaulon, 2 espécies a $P$. subg. Xeractis e 1 espécie a $P$. subg. Telxinöe. Com isso, constatou-se um acréscimo de 


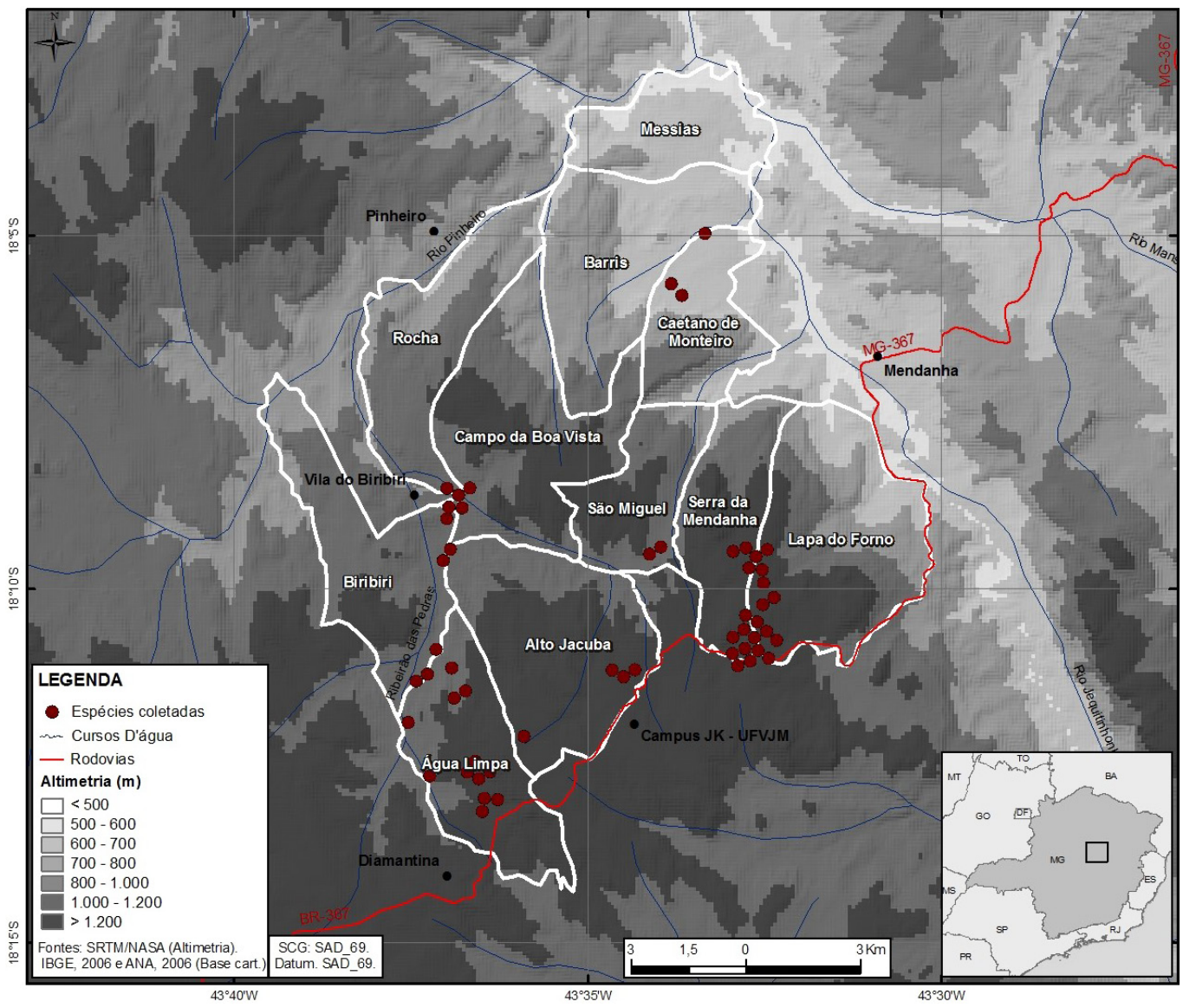

Figura 1 - Mapa de distribuição de Paepalanthus no Parque Estadual do Biribiri, segundo os diversos setores delimitados na área. Figure 1 - Distribution map of Paepalanthus at Biribiri State Park, according to the various sectors demarcated in the area.

13 espécies à listagem preliminar apresentada por Echternacht et al. (2012), que já havia apontado o PEBI como o mais rico em Eriocaulaceae dentre as Unidades de Conservação Estaduais de Minas Gerais. O número de espécies de Paepalanthus do PEBI é cerca de $25 \%$ do total de espécies do gênero no Planalto de Diamantina, isso em uma área que representa apenas $2 \%$ do total. Das 33 espécies registradas no PEBI, 19 (cerca de 60\%) são endêmicas da Cadeia do Espinhaço.

O gênero está distribuído amplamente no PEBI, com maior riqueza e diversidade de espécies em regiões de campo rupestre e altitudes elevadas, geralmente superiores a 800 metros. $\mathrm{O}$ intenso esforço amostral nas diferentes regiões do Parque garantiu a amostragem de espécies endêmicas e micro-endêmicas, como Paepalanthus bonsai Trovó \& Sano, P. capillifolius Moldenke, $P$. regelianus Koern. e P. rufo-albus Silveira.
Dentre as espécies registradas, três (Paepalanthus argenteus (Bong.) Koern., P. comans Silveira e $P$. macrocephalus (Bong.) Koern) se mostraram bastante frequentes, foram encontradas em quase todas as localidades, sendo espécies abundantes também em todo o Planalto de Diamantina. No entanto, Paepalanthus bifidus (Schrad) Kunth, P. ruficeps Ruhland e $P$. sphaerocephalus Ruhland foram amostradas em apenas três localidades e as demais espécies, em geral, mostraram-se restritas a não mais do que duas localidades. A região com maior riqueza de espécies (17 spp.) foi o setor denominado Lapa do Forno, com quase metade destes sendo novos registros para o PEBI. Isso se deve ao fato de a região ser pouco amostrada e pouco conhecida por pesquisadores, que sempre concentraram as coletas na região de Água Limpa, local situado na entrada do PEBI e que dá acesso às cachoeiras. 
Chave para as espécies de Paepalanthus do Parque Estadual do Biribiri, Minas Gerais

1. Capítulos sésseis

17. Paepalanthus leucocephalus

1'. Capítulos com escapos.

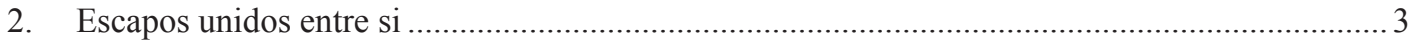

3. Escapos completamente unidos até a base do capítulo ........................................................ 4

4. Caule visivelmente alongado, $>10 \mathrm{~cm}$ de compr .......... 19. Paepalanthus macropodus

4'. Caule curto, restrito à roseta, até $2 \mathrm{~cm}$ compr..................21. Paepalanthus planifolius

3'. Escapos parcialmente unidos na base, tornando-se livres à partir do terço superior ............ 5

5. Espatas presentes.....................................................30. Paepalanthus trichopetalus

5'. Espatas ausentes ...........................................................32. Paepalanthus villosulus

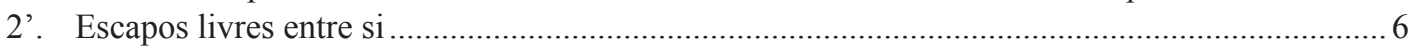

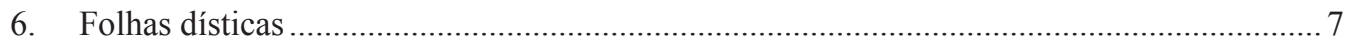

7. Caule alongado, $>30 \mathrm{~cm}$ de compr., folhas equitantes, capítulos alvos.

13. Paepalanthus distichophyllus

7'. Caule curto, $<2 \mathrm{~cm}$ de compr., folhas patentes, capítulos amarelos.

25. Paepalanthus ruficeps

6'. Folhas espiraladas

11. Paepalanthus chiquitensis

8. Eixo reprodutivo presente

8

8'. Eixo reprodutivo ausente.

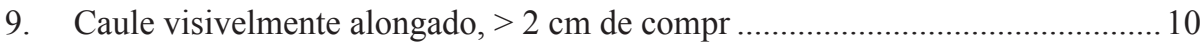

10. Escapos partindo de apenas um verticilo no ápice do caule......................... 11

11. Brácteas involucrais verdes superando a altura das flores

5. Paepalanthus bifidus

11'. Brácteas involucrais castanhas não superando a altura das flores.

1. Paepalanthus albiceps

10'. Escapos partindo de mais de um verticilo ao longo do caule.

12. Folhas capiláceas

10. Paepalanthus capillifolius

12'. Folhas lanceoladas, lineares ou falciformes

13. Plantas delgadas, caule tenro, não lignificado, $<2 \mathrm{~mm}$ de diâm.....

14. Brácteas involucrais creme a hialinas.

15. Plantas $>10 \mathrm{~cm}$ alt. Flores dímeras

15. Paepalanthus flaccidus

15'. Plantas $<8 \mathrm{~cm}$ alt. Flores trímeras

2. Paepalanthus albidus

14'. Brácteas involucrais marrom escuras

8. Paepalanthus bryoides

13'. Plantas rijas, caule lignificado, $>5$ mm de diâm.......................... 16

16. Caule ramificado dicotomicamente ................................... 17

17. Plantas $<10 \mathrm{~cm}$ alt. Caule coberto por bainha das folhas velhas, folhas verdes restritas ao ápice

6. Paepalanthus bonsai

17'. Plantas $>20 \mathrm{~cm}$ de alt. Folhas verdes persistentes dispostas ao longo do caule

16. Paepalanthus glaziovii

16'. Caule ramificado não dicotomicamente

18. Planta $>1$ metro de altura, escapos numerosos partindo de axilas foliares

22. Paepalanthus polygonus

18'. Planta $<45 \mathrm{~cm}$ de altura, um único escapo por axila foliar 
19. Plantas cespitosas, caule coberto por bainha das folhas velhas, lâminas foliares restritas ao ápice.

19'. Plantas isoladas, folhas espiraladas dispostas ao longo de todo o caule.

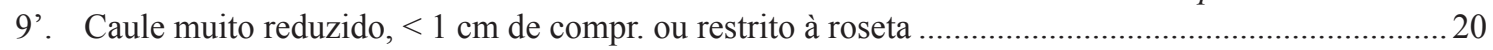

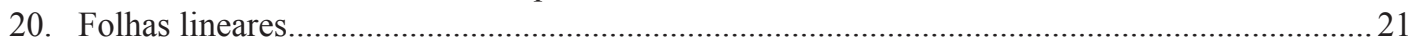

21. Folhas decíduas, numerosos escapos por indivíduo, glabros, flores 3-meras, anteras bitecas biesporangiadas

27. Paepalanthus scirpeus

21'. Folhas persistentes, até 3 escapos por indivíduo, pilosos, flores 2-meras, anteras bitecas tetraesporangiadas. 28. Paepalanthus sphaerocephalus

20'. Folhas lanceoladas 22

22. Brácteas involucrais ultrapassando a altura das flores no capítulo ..................................... 23

23. Brácteas das séries mais externas ultrapassando a altura das flores, não mais que seis brácteas, corola da flor estamina glabra no interior do tubo....

33. Paepalanthus xanthopus

23'. Brácteas das séries mais internas ultrapassando a altura das flores, sempre mais que seis, corola a flor estaminada pilosa no interior do tubo

24. Brácteas involucrais creme a douradas, folhas seríceas

4. Paepalanthus argenteus

24'. Brácteas involucrais marrom-escuras, folhas glabrescentes

12. Paepalanthus comans

22'. Brácteas involucrais não ultrapassando a altura das flores no capítulo

25. Planta $\leq 10 \mathrm{~cm}$ de altura, um a três escapos por roseta, folhas vilosas

3. Paepalanthus aretioides

25'. Planta $>12 \mathrm{~cm}$ de altura, escapos numerosos, folhas glabras ou pilosas.....................26

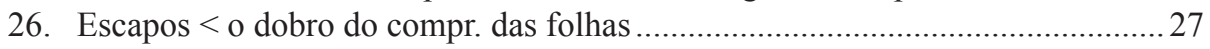

27. Folhas lanceoladas, ciliadas, vários escapos por axila foliar, capítulos hemisféricos 14. Paepalanthus eriophaeus

27'. Folhas oblongas a lineares, glabras, um escapo por axila foliar, capítulos esféricos. 7. Paepalanthus brunnescens

26'. Escapos > o dobro do compr. das folhas..... 28

28. Folhas $>15 \mathrm{~cm}$ de compr

24. Paepalanthus regelianus

$28^{\prime}$. Folhas $\leq 10 \mathrm{~cm}$ .29

29. Folhas pilosas

23. Paepalanthus pubescens

29'. Folhas pubescentes a glabras. 30

30. Escapos vilosos ou seríceos. 31

31. Escapos com pilosidade serícea a partir da metade superior, conferindo-lhes coloração prateada.

18. Paepalanthus macrocephalus

31'. Escapos vilosos, castanhos 29. Paepalanthus subfalcatus

30'. Escapos glabros a glabrescentes

32. Flores dímeras . .32

32'. Flores trímeras 31. Paepalanthus vaginatus 20. Paepalanthus pedunculatus

1. Paepalanthus albiceps Silveira, Floral. Mont.: 172. 1928.

Fig. 2a

Erva, 22-35 cm alt., caule aéreo alongado, não ramificado, coberto por bainha das folhas velhas ou não, até $10 \mathrm{~cm}$ compr., $0,5 \mathrm{~cm}$ diâm. Folhas planas, persistentes ou decíduas, espiraladas, dispostas ao longo do caule, $2-5 \times 0,5-0,8 \mathrm{~cm}$, lanceoladas, ápice agudo, pilosas em ambas as faces, com longos tricomas esparsos, ciliadas. Eixo reprodutivo ausente. Espatas 4-6 cm compr., pilosas a pubescentes, ápice agudo, margem inteira. Escapos verdes a castanhos, 12-25 cm 
compr., conjunto de escapos 10-20 por indivíduo, livres entre si, glabrescentes. Brácteas involucrais castanhas a marrom-escuras, obovadas, $2-3 \times 1-1,5$ $\mathrm{mm}$, ápice obtuso, as interiores um pouco mais claras, as internas mais longas que as externas, não ultrapassando a altura das flores, glabras na face abaxial, glabrescentes na face adaxial, margem ciliada. Capítulos alvos, 5-10 mm diâm. Brácteas florais hialinas, lanceoladas, 3-4×0,5 mm, ápice agudo a acuminado, ciliadas, membranáceas. Flores 3-meras; ca. 120 por capítulo, 2 vezes mais estaminadas que pistiladas; flores estaminadas $4 \times$ $2 \mathrm{~mm}$; pedicelo 1,2 mm de compr.; sépalas com 3 $\times 0,5 \mathrm{~mm}$, lanceoladas, hialinas, com pubescência em tufos na porção apical, tricomas curtos; corola hialina, $3 \times 0,5 \mathrm{~mm}$; glabra no interior do tubo, estames $1 \mathrm{~mm}$ compr., livres das pétalas, anteras bitecas tetraesporangiadas, hialinas, pistilódios 0,4 mm compr; flores pistiladas 2-3 × $1 \mathrm{~mm}$; sésseis; sépalas $3 \times 0,5 \mathrm{~mm}$, lanceoladas, hialinas, com tricomas no ápice; pétalas $3 \times 0,5 \mathrm{~mm}$, lanceoladas, com tricomas nas margens e no ápice; ramos estigmáticos bífidos; apêndices (3) nectaríferos, 0,5 mm compr.; estaminódios 3 , escamiformes, $0,2 \mathrm{~mm}$ compr.

Paepalanthus albiceps possui caule alongado não ramificado, folhas com pilosidade esparsa característica (Fig. 2a), com longos tricomas, axila das folhas com grande quantidade de tricomas e brácteas involucrais castanho-avermelhadas a marrom-escuras, o que a diferencia das demais espécies de Paepalanthus ocorrentes na área de estudo. Ocorre no Planalto de Diamantina, Serra do Cabral e Serra de Grão Mogol (Silveira 1928). Habita solos arenosos entre rochas. Floresce entre dezembro e junho.

Material examinado selecionado: BRASIL. MINAS GERAIS: Diamantina, Parque Estadual do Biribiri, Lapa do Cupim, 16.V.2011, C.O. Andrino 164 (DIAM); estrada para Biribiri, cachoeira dos Cristais, 24.IV.2007, M. Trovó \& M.T.C. Watanabe 371 (SPF).

2. Paepalanthus albidus Gardner, Icon. Pl. 6: t. 525. 1843.

Fig. 2b

Erva, 2-6 cm alt., caule aéreo alongado, ramificado, não ultrapassando $2 \mathrm{~cm}$ compr., 0,5 mm diâm. Folhas planas, persistentes, rosuladas ou dispostas ao longo do caule e congestas no ápice, 3-6 × $1 \mathrm{~mm}$, lineares, ápice agudo, densamente pilosas em ambas as faces. Eixo reprodutivo ausente. Espatas 2-4 mm compr., pilosas, ápice truncado, margem irregular. Escapos verdes a castanhos, 1-4 cm compr., conjunto de escapos 1-5 por indivíduo, livres entre si, glabrescentes. Brácteas involucrais hialinas, ovadas, 1-1,5 × $1 \mathrm{~mm}$, ápice agudo, não ultrapassando a altura das flores, glabras em ambas as faces, margem ciliada. Capítulos alvos, 5-18 mm diâm. Brácteas florais hialinas, lanceoladas, $1 \times 0,5 \mathrm{~mm}$, ápice agudo, ciliadas, membranáceas. Flores 3-meras; ca. 22 por capítulo, 2 vezes mais estaminadas que pistiladas; flores estaminadas $1 \times 0,3 \mathrm{~mm}$; pedicelo 0,2 $\mathrm{mm}$ de compr.; sépalas com $1 \times 0,5$ $\mathrm{mm}$, lanceoladas, hialinas, com pubescência em tufos na porção apical, tricomas longos; corola hialina, 0,7 ×0,3 mm; glabra no interior do tubo, estames $0,5 \mathrm{~mm}$ compr., livres das pétalas, anteras bitecas biesporangiadas, hialinas, pistilódios 0,1 $\mathrm{mm}$ compr; flores pistiladas $0,6-0,8 \times 0,5 \mathrm{~mm}$; sésseis; sépalas $1 \times 0,6 \mathrm{~mm}$, lanceoladas, hialinas, com tricomas no ápice; pétalas $0,8 \times 0,5 \mathrm{~mm}$, lanceoladas, com tricomas nas margens e no ápice; ramos estigmáticos bífidos; apêndices (3) nectaríferos, 0,2 mm compr.; estaminódios 3, escamiformes, 0,3 mm compr.

Paepalanthus albidus é facilmente distinguida pelo pequeno porte, capítulos alvos, brácteas involucrais hialinas e anteras biesporangiadas. A espécie é registrada apenas para o Planalto de Diamantina. Habita sombra de afloramentos rochosos. Floresce no período chuvoso, entre os meses de outubro a abril.

Material examinado: BRASIL. MINAS GERAIS: Diamantina, Parque Estadual do Biribiri, estrada Diamantina a Corinto, 20.I.1972, G. Hatschbach et al. 29028 (MBM).

3. Paepalanthus aretioides Ruhland in Engl.,Pflanzenr. 4, Fam. 30: 164. 1903. Fig. 2c Erva, 4-8 cm alt., caule subterrâneo, ramificado. Folhas planas, persistentes, rosuladas, $2-15 \times 1-3 \mathrm{~mm}$, lanceoladas, ápice agudo, velutinas na face adaxial em direção ao ápice, pubescentes ou glabras, pubescentes na face abaxial. Eixo reprodutivo ausente. Espatas 0,5-1,5 cm compr., pilosas a pubescentes, ápice agudo, margem inteira. Escapos verdes a castanhos, 2-4 cm compr., 1 escapo por indivíduo, pubescentes. Brácteas involucrais castanhas a marrom escuras, triangulares a ovadas, 2-4 × 1-1,5 mm, ápice acuminado, as exteriores um pouco mais claras, as internas mais longas que as externas, não ultrapassando a altura das flores, glabrescentes em ambas as faces, margem ciliada. Capítulos 
alvos, 5-10 mm diâm. Brácteas florais marromescuras, lanceoladas, $2 \times 0,5 \mathrm{~mm}$, ápice agudo, ciliada, membranáceas. Flores 3-meras; ca. 110 por capítulo, 3 vezes mais estaminadas que pistiladas; flores estaminadas $2 \times 0,5 \mathrm{~mm}$; pedicelo $0,5 \mathrm{~mm}$ de compr.; sépalas com $2 \times 0,5 \mathrm{~mm}$, lineares a lanceoladas, castanhas, com pubescência em tufos na porção apical, corola creme, 1,5 × $1 \mathrm{~mm}$; glabra no interior do tubo, estames $2 \mathrm{~mm}$ compr., livres das pétalas, anteras bitecas tetraesporangiadas, creme, pistilódios $0,5 \mathrm{~mm}$ compr; flores pistiladas $3 \times 0,5 \mathrm{~mm}$; pedicelo $0,5 \mathrm{~mm}$ compr.; sépalas $2 \times 0,5 \mathrm{~mm}$, lanceoladas, castanhas a marrom escuras, com tricomas no ápice; pétalas $1,5 \times 0,5$ $\mathrm{mm}$, lanceoladas, com tricomas nas margens e no ápice; ramos estigmáticos bífidos; apêndices (3) nectaríferos, 0,3 mm compr.; estaminódios 3 , escamiformes, 0,2 $\mathrm{mm}$ compr.

Paepalanthus aretioides pode ser facilmente reconhecida pelo hábito agregado, caule curto lignificado e folhas rosuladas. A pilosidade das folhas apresenta variação de acordo com a estação em que foi produzida: nos períodos secos os tricomas tendem a cobrir toda a superfície adaxial das folhas, no período chuvoso esta pilosidade pode se restringir à metade superior da folha ou até mesmo estar ausente. É endêmica do Planalto de Diamantina, no PEBI foi encontrada na porção Sul/Sudeste. Habita solos arenosos ou arenoquartizíticos e em pleno sol. Floresce durante praticamente todo o ano.

Material examinado selecionado: BRASIL. MINAS GERAIS: Diamantina, Parque Estadual do Biribiri, trilha para o alto da cachoeira da Sentinela, 18.XI.2010, C.O. Andrino et al. 81 (DIAM).

4. Paepalanthus argenteus (Bong.) Koern. in Mart., Fl. bras. 3(1): 343. $1863 . \quad$ Fig. 2d-f

Erva, 15-42 cm alt., caule aéreo curto, restrito à roseta, até $3 \mathrm{~cm}$ diâm. Folhas planas, persistentes, rosuladas, $(2,5-) 6-35,5 \times(0,3-) 0,6-2$ $\mathrm{cm}$, lanceoladas, ápice agudo, densamente seríceas na face abaxial, seríceas a pubescentes na face adaxial. Eixo reprodutivo ausente. Espatas 1,4-6,5 cm compr., pilosas a pubescentes, ápice arredondado a agudo, margem irregular. Escapos verdes a castanhos, 4,5-37 cm compr., conjunto de escapos 2-16 por indíviduo, livres entre si, densamente pilosos a pubescentes. Brácteas involucrais creme a douradas, triangulares, 5-11 $\times 2-6 \mathrm{~mm}$, ápice agudo, as interiores um pouco mais claras, as internas mais longas que as externas, ultrapassando a altura das flores em 1-6 mm, pubescentes na face abaxial, pilosas na face adaxial. Capítulos ocre, 5-18 mm diâm. Brácteas florais hialinas, lanceoladas, $4 \times 0,5 \mathrm{~mm}$, ápice agudo a acuminado, ciliada, membranácea. Flores 3-meras; ca. 114 por capítulo, 2 vezes mais estaminadas que pistiladas; flores estaminadas $4 \times 2 \mathrm{~mm}$; pedicelo $1,2 \mathrm{~mm}$ compr.; sépalas com $3 \times 0,5 \mathrm{~mm}$, elípticas a oblanceoladas, hialinas, com pubescência em tufos na porção apical, tricomas curtos; corola hialina, $3,5 \times 1 \mathrm{~mm}$; pilosa no interior do tubo, estames $3 \mathrm{~mm}$ compr., livres das pétalas, anteras bitecas, tetraesporangiadas, hialinas, pistilódios 0,4 mm compr.; flores pistiladas 4-6 × 1,5-2 mm; sésseis; sépalas 3,5-5 × 0,8-1 mm, obovadas, hialinas, com tricomas apicais; pétalas 3-4,5 $\times$ $1,5 \mathrm{~mm}$, lanceoladas, com tricomas nas margens e no ápice; ramos estigmáticos bífidos; apêndices (3) nectaríferos, 1,5 mm compr.; estaminódios 3, escamiformes, 0,3 mm compr.

Paepalanthus argenteus pode ser facilmente distinguida pelas brácteas involucrais douradas ultrapassando a altura das flores e pela pilosidade serícea das folhas (Fig. 2). É a espécie mais comum no PEBI, ocorrendo em toda a área do Parque. Geralmente habita solos profundos e bem drenados. $E$ endêmica da Cadeia do Espinhaço em Minas Gerais, estando amplamente distribuída ao longo de toda a Cadeia, com populações numerosas (Hensold 1988). Floresce durante todo o ano, com pico de floração nos meses de janeiro e fevereiro. Material examinado selecionado: BRASIL. MINAS GERAIS: Diamantina, Parque Estadual do Biribiri, trilha para o alto da cachoeira da Sentinela, 18.XII.2010, C.O. Andrino et al. 87, (DIAM); Lapa do Forno, 12.I.2011, C.O. Andrino et al. 108 (DIAM).

5. Paepalanthus bifidus (Schrad.) Kunth., Enum. P1. 3: 512. 1841.

Fig. $2 \mathrm{~g}$

Erva, 2-9 cm alt., caule aéreo alongado, até $7 \mathrm{~cm}$ compr., $2 \mathrm{~mm}$ diâm. Folhas planas, persistentes, espiraladas, dispostas ao longo do caule, 9-25 × 1-2 mm, lanceoladas, agudas, pilosas em ambas as faces, longos tricomas esparsos. Eixo reprodutivo ausente. Espatas 4-8 mm compr., pilosas, ciliadas, ápice agudo, margem oblíqua. Escapos verdes a castanhos, 1-7 cm compr., conjunto de escapos 2-20 por indivíduo, livres entre si, pilosos. Brácteas involucrais verdes a douradas, lanceoladas, $1-2 \times 1 \mathrm{~mm}$, ápice agudo, as interiores um pouco mais claras, as externas mais longas que as internas, ultrapassando a altura 
das flores em 1-2 mm, glabras em ambas as faces, margem ciliada. Capítulos alvos, 4-5 mm diâm. Brácteas florais hialinas, lanceoladas, $2 \times 0,5 \mathrm{~mm}$, ápice agudo a acuminado, ciliadas, membranáceas. Flores 3-meras; ca. 40 por capítulo, 4 vezes mais estaminadas que pistiladas; flores estaminadas $1-2 \times 3 \mathrm{~mm}$; pedicelo $0,8 \mathrm{~mm}$ de compr.; sépalas com 1,2-2 × 0,5-0,8 mm, elípticas a obovadas, hialinas, com pubescência em tufos no ápice, tricomas curtos; corola hialina, glabra no interior do tubo, $1 \times 2 \mathrm{~mm}$; estames $3 \mathrm{~mm}$ compr., livres das pétalas, anteras bitecas tetraesporangiadas, hialinas, pistilódios 0,2 mm compr.; flores pistiladas 1-2,5 $\times 0,5-1 \mathrm{~mm}$; sésseis; sépalas $1-1,5 \times 0,5-0,8 \mathrm{~mm}$, obovadas, hialinas, com tricomas no ápice; pétalas 1,5-2 $\times 0,5 \mathrm{~mm}$, obovadas, com tricomas nas margens e no ápice; ramos estigmáticos simples; estaminódios ausentes.

Paepalanthus bifidus pode ser distinguida pelo caule delgado alongado, nunca ramificado, pelos escapos fasciculados no ápice caulinar e pelas brácteas involucrais verdes ultrapassando a altura das flores no capítulo, geralmente em duas séries. A espécie é amplamente distribuída na América do Sul, ocorrendo nos Tepuis venezuelanos, Suriname, Colômbia e, no Brasil, onde ocorre em todas as regiões do país (Ruhland 1903). Foi coletada com flores durante todo o ano, em solos arenosos, argilosos e em fendas de rocha.

Material examinado selecionado: BRASIL. MINAS GERAIS: Diamantina, Parque Estadual do Biribiri, estrada para Biribiri, 8.IV.1982, N. Hensold et al. CFCR 3108 (SPF); campinas dos Barris, 17.VII.2008, L. Echternacht \& T.V. Bastos 1822 (SPF).

\section{Paepalanthus bonsai Trovó \& Sano, Novon} 19(3): 412. 2009.

Fig. 2h

Erva, 6-10 cm alt., caule aéreo alongado, coberto por bainha das folhas, ramificado dicotomicamente, até $9 \mathrm{~cm}$ compr, $0,5 \mathrm{~cm}$ diâm. Folhas planas, decíduas, rosuladas, restritas ao ápice do caule, 3-6 × 0,1 cm, lineares ou falciformes, agudas, pubescentes em ambas as faces, com longos tricomas na axila das folhas. Eixo reprodutivo ausente. Espatas 1-3 mm compr., ciliada, glabrescentes, ápice truncado, margem irregular. Escapos verdes a castanhos, 0,5-1 cm compr., conjunto de escapos 2-16 por indíviduo, livres entre si, glabrescentes. Brácteas involucrais marrons, ovadas, 1-2 × 1-2 mm, ápice obtuso, as interiores um pouco mais claras, as internas mais longas que as externas, não ultrapassando a altura das flores, glabrescentes em ambas as faces, pilosas na porção distal da face adaxial, ciliadas. Capítulos alvos, $5 \mathrm{~mm}$ diâm. Brácteas florais hialinas, oblongas, $3 \times 1 \mathrm{~mm}$, ápice agudo, ciliada, membranácea. Flores 3 -meras; ca. 40 por capítulo: 5 vezes mais estaminadas que pistiladas; flores estaminadas $3 \times 1 \mathrm{~mm}$; pedicelo $1 \mathrm{~mm}$ compr.; sépalas com $3 \times 0,5 \mathrm{~mm}$, oblongas, hialinas, com pubescência em tufos na porção apical, tricomas curtos; corola hialina, $3 \times 0,5 \mathrm{~mm}$; glabra no interior do tubo, estames $1 \mathrm{~mm}$ compr., livres das pétalas, anteras bitecas, tetraesporangiadas, hialinas, pistilódios $0,4 \mathrm{~mm}$ compr.; flores pistiladas $3 \times 0,7 \mathrm{~mm}$; sésseis; sépalas $3 \times 0,5 \mathrm{~mm}$, obovadas, hialinas, com tricomas no ápice; pétalas $3 \times 0,5 \mathrm{~mm}$, lanceoladas, com tricomas nas margens e no ápice; ramos estigmáticos bífidos; apêndices (3) nectaríferos, $1 \mathrm{~mm}$ compr.; estaminódios 3, escamiformes, 0,1 mm compr.

Paepalanthus bonsai é caracterizada por possuir caule dicotomicamente ramificado formando pequenas touceiras, folhas lineares rígidas presentes apenas nos ápices caulinares, sendo o restante do caule recoberto por bainhas persistentes. Ocorre diretamente sobre as rochas, o que é raro em Paepalanthus. É uma espécie microendêmica, restrita a pequenas populações em alguns afloramentos rochosos na região do Planalto de Diamantina. Floresce entre os meses de agosto e novembro.

Material examinado: BRASIL. MINAS GERAIS: Diamantina, Parque Estadual do Biribiri, Lapa do Forno, 15.IX.2012, C.O. Andrino 235 (SPF).

7. Paepalanthus brunnescens Ruhland in Engl., Pflanzenr. 4, Fam. 30: 136. 1903

Erva, 11-20 cm alt., caule aéreo curto, restrito à roseta, até $2 \mathrm{~cm}$ diâm. Folhas planas, persistentes, rosuladas, $2-9 \times 0,2-0,5 \mathrm{~cm}$, lineares a lanceoladas, agudas, puberulentas em ambas as faces. Eixo reprodutivo ausente. Espatas 1,5-4 cm compr., puberulas a pubescentes, ápice agudo, margem inteira. Escapos castanhos, 3-16 cm compr., conjunto de escapos 1-31 por indivíduo, livres entre si, glabros. Brácteas involucrais castanhas, lanceoladas a ovadas, $2-3 \times 1,5-2,5$ $\mathrm{mm}$, ápice agudo, as interiores um pouco mais escuras, as internas mais curtas que as externas, não ultrapassando a altura das flores, glabrescentestes em ambas as faces, margem ciliada. Capítulos castanhos, 4-6 mm diâm. Brácteas florais hialinas a castanhas, oblanceoladas a obtruladas, 1-1,5 
$\times 0,4 \mathrm{~mm}$, ápice truncado a acuminado, ciliada, membranácea. Flores 3-meras; ca. 76 por capítulo, 2 vezes mais estaminadas que pistiladas; flores estaminadas $2 \times 1 \mathrm{~mm}$; pedicelo $1,5 \mathrm{~mm}$ de compr.; sépalas com $1,5 \times 0,5 \mathrm{~mm}$, elípticas a oblanceoladas, castanhas, ciliadas no ápice, tricomas curtos; corola hialina, $1 \times 0,5 \mathrm{~mm}$; glabra no interior do tubo, estames $1 \mathrm{~mm}$ compr., livres das pétalas, anteras bitecas, tetraesporangiadas, castanho-escuras, pistilódios $0,5 \mathrm{~mm}$ compr.; flores pistiladas 2-3 × 1-2 mm; sésseis; sépalas 3,5-5 × 0,8-1 mm, oblanceoladas a obtruladas, castanhas, com tricomas no ápice; pétalas $1,5-1 \times$ $0,5 \mathrm{~mm}$, oblanceoladas, com tricomas nas margens e no ápice; ramos estigmáticos bífidos; apêndices (3) nectaríferos, $1 \mathrm{~mm}$ compr.; estaminódios 3 , escamiformes, 0,2 $\mathrm{mm}$ compr.

Paepalanthus brunnescens é registrada na área de estudo apenas pelo espécime-tipo, coletado por Glaziou em 1892, que apontou "Biribiry" como localidade da coleta. O tipo foi analisado por fotografia disponibilizada pelo herbário de Berlim e a descrição da espécie baseou-se em apenas dois materiais disponíveis nos herbários brasileiros. Segundo Ruhland (1903), as características distintivas da espécie são as folhas oliváceas e os escapos e brácteas castanho-claros. Foi coletada com flores em julho e setembro.

Material adicional examinado: BRASIL. MINAS GERAIS: Lima Duarte, Gruta do Pião, Serra do Ibitipoca, 19.IX.1940, M. Magalhães 536 (BHCB); Santo Antonio do Itambé, Parque Estadual Pico do Itambé, 14.VII.2008, L. Echternacht \& T.V. Bastos 1776 (SPF).

\section{Paepalanthus bryoides Kunth, Enum. P1. 3: 520.} 1841.

Fig. $2 \mathrm{i}$

Erva, 14-55 cm alt., caule aéreo muito reduzido, não ultrapassando $4 \mathrm{~cm}$ compr. e $2 \mathrm{~mm}$ diâm. Folhas planas, persistentes, espiraladas dispostas ao longo do caule, 0,9-2,5 × 0,1-0,2 $\mathrm{cm}$, lineares, agudas, pilosas a glabrescentes em ambas as faces, longos tricomas esparsos. Eixo reprodutivo ausente. Espatas 2-4 mm compr., pilosas, ciliadas, ápice truncado e margem serreada. Escapos verdes a castanhos, 1-2 cm compr., escapos solitários ao longo do caule, livres entre si, pilosos. Brácteas involucrais marrom- escuras, obovadas a orbiculares, 1-2 1 mm, ápice arredondado, internas e externas do mesmo tamanho, não ultrapassando a altura das flores, glabras em ambas as faces, margem ciliada, longos tricomas. Capítulos alvos, 1-3 mm diâm. Brácteas florais hialinas, obovadas, $2 \times 0,5 \mathrm{~mm}$, ápice arredondado, ciliada, membranácea. Flores 3-meras; ca. 20 por capítulo, 2 vezes mais estaminadas que pistiladas; flores estaminadas $0,5-1 \times 0,5 \mathrm{~mm}$; pedicelo 0,2 mm de compr.; sépalas com 0,4-0,8 × 0,5 mm, elípticas a obovadas, hialinas, com pubescência em tufos no ápice, tricomas longos; corola hialina, glabra no interior do tubo, 0,5-1 × $0,5 \mathrm{~mm}$; estames ca. 0,8 mm compr., livres das pétalas, anteras bitecas biesporangiadas, despigmentadas, pistilódios 0,3 mm; flores pistiladas $0,8-2 \times 0,5$ $\mathrm{mm}$; sésseis; sépalas $1-1,5 \times 0,5 \mathrm{~mm}$, obovadas, hialinas, com tricomas no ápice; pétalas $1,5-2 \times$ $0,5 \mathrm{~mm}$, obovadas, com tricomas nas margens e no ápice; ramos estigmáticos simples; estaminódios inconspícuos.

Paepalanthus bryoides pode ser distinguida das demais espécies pelo pequeno porte, caule delgado visivelmente alongado, folhas lineares e pelas brácteas involucrais arredondadas marromescuras a enegrecidas. A espécie ocorre em Santa Catarina e Minas Gerais (Giulietti et al. 2014), com registros de ocorrência de muitas populações, no Parque foi encontrada apenas uma população na porção leste, em solo arenoso de fenda de rocha. Floresce durante todo o ano.

Material examinado selecionado: BRASIL. MINAS GERAIS: Diamantina, Parque Estadual do Biribiri, Lapa do Forno, 19.V.2011, C.O. Andrino 167 (DIAM); campo um pouco antes da Serra do Gombô, 23.II.2010, F.N. Costa et al. 1216 (DIAM).

\section{Paepalanthus canescens (Bong.) Koern. in} Mart., Fl. bras. 3(1): 381. 1863.

Fig. 2j

Erva, 15-42 cm alt., caule aéreo alongado, coberto por bainha das folhas velhas, ramificado ou não, até $20 \mathrm{~cm}$ compr., 0,2 mm diâm. Folhas planas, persistentes ou decíduas, espiraladas, distribuídas ao longo do caule, $1-4 \times 0,1-0,4 \mathrm{~cm}$, lanceoladas, agudas, pilosas na face adaxial, pubescentes na face abaxial. Eixo reprodutivo ausente. Espatas 3-4 cm compr., pilosas a pubescentes, ápice agudo, margem inteira. Escapos verdes a castanhos, 7-15 cm compr., conjunto de escapos 2-7 por indivíduo, livres entre si, pilosos. Brácteas involucrais creme a douradas, triangulares a obovadas, 2-3 $\times 2 \mathrm{~mm}$, ápice obtuso, as internas mais longas que as externas, não ultrapassando a altura das flores, pubescentes em ambas as faces. Capítulos alvos, 4-8 mm diâm. Brácteas florais hialinas, lanceoladas, $4 \times 0,5 \mathrm{~mm}$, ápice arredondado, ciliada, membranácea. Flores 3-meras; ca. 160 por 


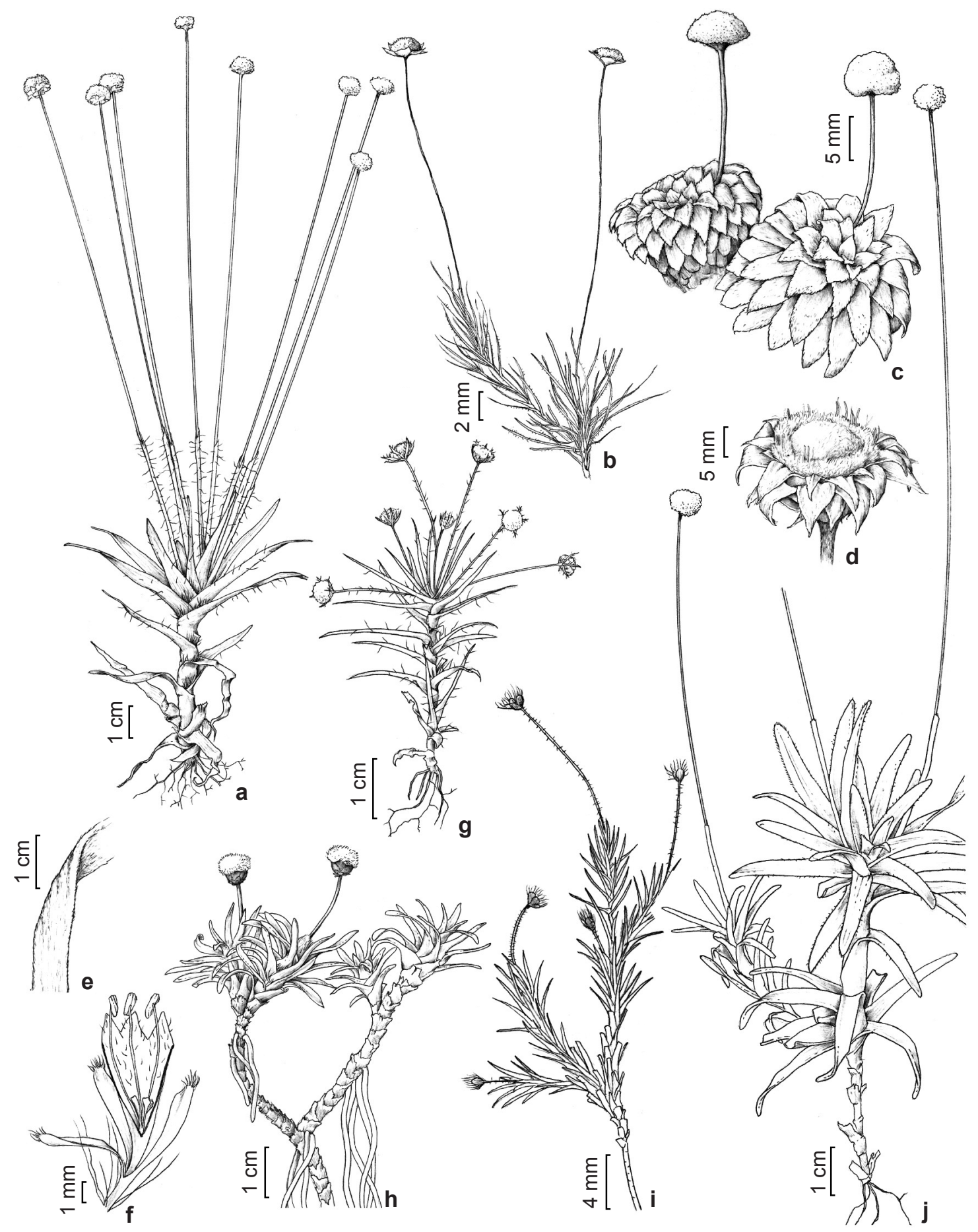

Figura 2 - a. Paepalanthus albiceps, hábito; b. Paepalanthus albidus, ramo; c. Paepalanthus aretioides, hábito; d-f. Paepalanthus argenteus - d. Capítulo; e. detalhe da folha; f. corola da flor estaminada; g. Paepalanthus bifidus, hábito; h. Paepalanthus bonsai, ramo; i. Paepalanthus bryoides, ramo; j. Paepalanthus canescens, hábito. (Ilustrado por Marcelo Kubo). Figure 2 - a. Paepalanthus albiceps, habit; b. Paepalanthus albidus, branch; c. Paepalanthus aretioides, habit; d-f. Paepalanthus argenteus - d. Capitulum; e. detail of leaf; f. corolla of staminate flower; g. Paepalanthus bifidus, habit; h. Paepalanthus bonsai, branch; i. Paepalanthus bryoides, branch; j. Paepalanthus canescens, habit. (Line drawing by Marcelo Kubo). 
capítulo, 6 vezes mais estaminadas que pistiladas; flores estaminadas 2-3 $21 \mathrm{~mm}$; pedicelo $1 \mathrm{~mm}$ de compr.; sépalas $2 \times 0,5 \mathrm{~mm}$, oblanceoladas, hialinas, com pubescência em tufos na porção apical, tricomas curtos; corola hialina, 1,5 $\times$ $1 \mathrm{~mm}$; glabra no interior do tubo, estames 1 $\mathrm{mm}$ compr., livres das pétalas, anteras bitecas, tetraesporangiadas, hialinas, pistilódios $0,2 \mathrm{~mm}$ compr; flores pistiladas 2-3 × 0,5-1 mm; sésseis; sépalas $2 \times 0,5 \mathrm{~mm}$, oblanceoladas, creme, com tricomas no ápice; pétalas $2 \times 0,5 \mathrm{~mm}$, lanceoladas, com tricomas nas margens e no ápice; ramos estigmáticos bífidos; apêndices (3) nectaríferos, $1 \mathrm{~mm}$ compr.; estaminódios 3, escamiformes, 0,1 $\mathrm{mm}$ compr.

Paepalanthus canescens possui hábito semelhante a $P$. albiceps, com o caule alongado e folhas espiraladas dispostas ao longo do caule, sendo por essa razão, algumas vezes confundidas em material herborizado. Podem ser distinguidas pela pilosidade e textura das folhas, mais facilmente visualizada em campo. Paepalanthus canescens possui folhas mais delicadas e pilosas em ambas as faces, com tricomas curtos, além de apresentar ramificações no caule em alguns indivíduos, o que não ocorre em $P$. albiceps. A espécie ocorre no Planalto de Diamantina e na Chapada dos Veadeiros em Goiás (Silveira 1928). Habita solos arenosos. Floresce durante todo o ano.

Material examinado selecionado: BRASIL. MINAS GERAIS: Diamantina, Parque Estadual do Biribiri, trilha para o alto da cachoeira da Sentinela, 1.VI.2011, C.O. Andrino \& M.M. Cota 177 (DIAM); estrada para a vila do Biribiri, próx. à cachoeira da Sentinela, 16.VII.2008, L. Echternacht \& T.V. Bastos 1810 (SPF).

10. Paepalanthus capillifolius Moldenke, Phytologia 32: 485. $1976 . \quad$ Fig. 3a

Erva, 20-90 cm alt., caule aéreo alongado, ramificado até $85 \mathrm{~cm}$ compr., $3 \mathrm{~mm}$ diâm. Folhas capilares, persistentes, distribuídas ao longo do caule, marcescentes, $2-10 \times 0,02 \mathrm{~cm}$, agudas, pubescentes. Eixo reprodutivo ausente. Espatas 2-3 cm compr., pilosas a pubescentes, ápice agudo, margem inteira. Escapos verdes a castanhos, 2-7 cm compr., conjunto de escapos 4-8 por indivíduo, livres entre si, pubescentes. Brácteas involucrais marrons, obovadas, $1-3 \times 1 \mathrm{~mm}$, ápice obtuso, as interiores um pouco mais claras, as internas mais longas que as externas, não ultrapassando a altura das flores, pilosa na porção apical da face adaxial, ciliada. Capítulos alvos, 3-6 mm diâm. Brácteas florais hialinas, lanceoladas, 2-3 $\times 1 \mathrm{~mm}$, ápice agudo, ciliadas, membranáceas. Flores 3-meras; ca. 56 por capítulo, 6 vezes mais estaminadas que pistiladas; flores estaminadas 3 $\times 1 \mathrm{~mm}$; pedicelo $1 \mathrm{~mm}$ compr.; sépalas $3 \times 0,5$ $\mathrm{mm}$, lanceoladas, hialinas, com pubescência em tufos na porção apical, tricomas curtos; corola hialina, $2 \times 0,5 \mathrm{~mm}$; glabra no interior do tubo, estames $1,5 \mathrm{~mm}$ compr., livres das pétalas, anteras bitecas, tetraesporangiadas, hialinas, pistilódios 0,5 $\mathrm{mm}$ compr; flores pistiladas $3 \times 1 \mathrm{~mm}$; sésseis; sépalas $3 \times 1 \mathrm{~mm}$, obovadas, hialinas, com tricomas no ápice; pétalas $2 \times 0,5 \mathrm{~mm}$, lanceoladas, com tricomas nas margens e no ápice; ramos estigmáticos bífidos; apêndices (3) nectaríferos, $0,5 \mathrm{~mm}$ compr.; estaminódios 3 , escamiformes, $0,2 \mathrm{~mm}$ compr.

Paepalanthus capilifollius possui hábito semelhante ao de $P$. distichophyllus, pode ser facilmente distinguida pelas folhas capiláceas característica que dá nome à espécie - espiraladas e dispostas ao longo do caule bastante alongado. Habita solos encharcados em borda de capão de mata e, geralmente em meio a gramíneas. É microendêmica do Planalto de Diamantina e era conhecida até o momento de apenas duas localidades, sua ocorrência no interior do Parque representa um novo registro de ocorrência. Provavelmente floresce no período chuvoso.

Material examinado: BRASIL. MINAS GERAIS: Diamantina, Parque Estadual do Biribiri, Alto da Jacuba, borda de capão de mata, 20.IX.2013, C.O. Andrino 230 (SPF);

11. Paepalanthus chiquitensis Herzog, Repert. Spec. Nov. Regni Veg. 20: 86. 1924.

Erva, 100-250 cm alt., caule aéreo curto, restrito à roseta, até $4 \mathrm{~cm}$ diâm. Folhas planas, persistentes, rosuladas, $14-35 \times 1-3 \mathrm{~cm}$, lanceoladas, agudas, glabrescente em ambas as faces, ciliadas ou não. Eixo reprodutivo ereto, 80 $220 \mathrm{~cm}$ compr.; Brácteas do eixo lanceoladas, 7-20 $\times 2-4 \mathrm{~cm}$ compr., as basais gradualmente maiores que as apicais, patentes, glabrescentes em ambas as faces. Espatas 3-6 cm compr., glabrescentes, ápice agudo, margem inteira ciliada ou não. Escapos verdes a castanhos, 10-30 cm compr., conjunto de escapos 240-450 por indivíduo, livres entre si, glabros. Brácteas involucrais marrom escuras, triangulares a obovadas, $2-5 \times 2-3 \mathrm{~mm}$, ápice agudo, as internas mais longas que as externas, não ultrapassando a altura das flores, pubescentes 
na face abaxial, glabras na face adaxial, ciliadas ou não. Capítulos alvos, 5-12 mm diâm. Brácteas florais creme a marrom-escuras, lineares a espatuladas, $3 \times 0,5 \mathrm{~mm}$, ápice agudo a obtuso, ciliada, membranácea. Flores 2-meras; ca. 500 por capítulo, 4 vezes mais estaminadas que pistiladas; flores estaminadas $4 \times 1 \mathrm{~mm}$; pedicelo $1,5 \mathrm{~mm}$ compr.; sépalas com $3 \times 0,5 \mathrm{~mm}$, oblanceoladas, creme a marrons na porção apical, com pubescência em tufos na porção apical, tricomas curtos; corola hialina a creme, $3,5 \times 1 \mathrm{~mm}$; glabra no interior do tubo, estames $2 \mathrm{~mm}$ compr., livres das pétalas, anteras bitecas, tetraesporangiadas, hialinas, pistilódios $1 \mathrm{~mm}$ compr; flores pistiladas 3-4 $\times$ 2-3 $\mathrm{mm}$; sésseis; sépalas $3 \times 2 \mathrm{~mm}$, obovadas, hialinas, com tricomas no ápice; pétalas $3-4,5 \times$ $1,5 \mathrm{~mm}$, espatuladas, com tricomas nas margens e no ápice; ramos estigmáticos bífidos; apêndices (2) nectaríferos, $1 \mathrm{~mm}$ compr.; estaminódios completamente reduzidos.

Paepalanthus chiquitensis é a única espécie de Paepalanthus registrada no PE do Biribiri que possui eixo reprodutivo, característica exclusiva da seção à qual pertence: $P$. sect Diphyomene. Além disso, pode ser facilmente reconhecida pelo hábito robusto, geralmente ultrapassando um metro de altura e pelas inflorescências em grandes umbelas no ápice do eixo. A espécie possui distribuição ampla, ocorrendo na Bolívia, Venezuela e Colômbia e, no Brasil, nos estados do Amazonas, Goiás, Mato Grosso, Mato Grosso do Sul, Minas Gerais, Pará, Rondônia, São Paulo e Tocantins (Trovó 2010). No Parque foi encontrada em duas localidades situadas no sul e no leste. Floresce durante todo o ano.

Material examinado selecionado: BRASIL. MINAS GERAIS: Diamantina, Parque Estadual do Biribiri, Lapa do Cupim, 16.V.2011, C.O. Andrino 163 (DIAM).

12. Paepalanthus comans Silveira, Floral. Mont.: 262. 1928.

Fig. 3b

Erva, 14-55 cm alt., caule aéreo curto, restrito à roseta, até $1 \mathrm{~cm}$ diâm. Folhas planas, persistentes, rosuladas, $3-13 \times 0,2-1,1 \mathrm{~cm}$, lanceoladas, agudas a obtusas, glabras em ambas as faces. Eixo reprodutivo ausente. Espatas 3-11,5 cm compr., glabrescentes, ápice agudo, margem inteira. Escapos verdes a castanhos, 12-44 cm compr., conjunto de escapos 3-10 por indíviduo, livres entre si, pubescentes a vilosos. Brácteas involucrais castanho-escuras, ovadas a triangulares, 4-7 × 2,5-5 mm, ápice agudo, as interiores um pouco mais escuras, as internas mais longas que as externas, ultrapassando a altura das flores em $0,8-3 \mathrm{~mm}$, glabras a pubescentes na face abaxial e pubescentes a lanosas no ápice da face adaxial. Capítulos alvos, 6-19 mm diâm. Brácteas florais hialinas, com pigmentação enegrecida na porção distal, lanceoladas, 5,7 ×0,4 mm, ápice arredondado a acuminado, ciliada, membranácea. Flores 3-meras, ca. 140 por capítulo, 3 vezes mais estaminadas que pistiladas; flores estaminadas 5 $\times 6 \mathrm{~mm}$; pedicelo $0,5-1 \mathrm{~mm}$ compr.; sépalas 4-6 $\times 0,5-1 \mathrm{~mm}$, elípticas a oblanceoladas, hialinas, ápice acuminado levemente mais escuro que a base, com pubescência em tufos na porção apical; corola hialina, $2,5 \times 1,5-2 \mathrm{~mm}$; pilosa no interior do tubo, estames $2-4 \mathrm{~mm}$ compr., livres das pétalas, anteras bitecas, tetraesporangiadas, hialinas, pistilódios 0,5-1 mm compr; flores pistiladas 3-5 $\times 1 \mathrm{~mm}$; sésseis; sépalas 3-5×0,5-1 mm, lineares a lanceoladas, hialinas, com tricomas no ápice; pétalas 3-4 × 0,6-1 mm, lanceoladas, com tricomas nas margens e no ápice; ramos estigmáticos bífidos; apêndices (3) nectaríferos, 1,5 mm compr.; estaminódios 3, escamiformes, 0,1-0,6 mm compr.

Além de possuir as brácteas involucrais ultrapassando a altura das flores no capítulo, como quase todas as espécies de Paepalanthus subg. Xeractis, $P$. comans pode ser facilmente reconhecida por possuir brácteas involucrais marrom-escuras, combinadas com a pigmentação enegrecida no ápice das brácteas florais, característica que pode ser vista em campo. Também apresentam folhas bastante enrugadas quando secas, devido a características do mesofilo (Hensold 1988). É endêmica dos campos rupestres do Planalto de Diamantina, sendo uma das espécies mais abundantes no Parque, juntamente com $P$. argenteus. Floresce durante a estação chuvosa, entre os meses de outubro a abril.

Material examinado selecionado: BRASIL. MINAS GERAIS: Diamantina, Parque Estadual do Biribiri, trilha para o alto da cachoeira Sentinela, 18.XII.2010, C.O. Andrino et al. 84 (DIAM); Lapa do Forno, 12.I.2011, C.O. Andrino \& I.M. Franco 109 (DIAM).

13. Paepalanthus distichophyllus Mart., Nova Acta Phys.-Med. Acad. Caes. Leop.-Carol. Nat. Cur. 17(1): 23. 1835.

Fig. 3c

Erva, 50-110 cm alt., caule aéreo, até 90 $\mathrm{cm}$ compr, até $1 \mathrm{~cm}$ diâm. Folhas conduplicadas, equitantes, persistentes, dísticas, marcescentes, $1,5-3 \times 0,5-1 \mathrm{~cm}$, lanceoladas, agudas, ápice espinescente, glabras em ambas as faces, ciliadas. 
Eixo reprodutivo ausente. Espatas 2-5 cm compr., glabra, ciliada, ápice truncado, margem irregular. Escapos verdes a castanhos, 5-34 cm compr., conjunto de escapos 2-6 por indíviduo, dispostos ao longo do caule, livres entre si, glabros. Brácteas involucrais castanhas, lanceoladas a obovadas, 3-4 $\times 2-3 \mathrm{~mm}$, ápice agudo a arredondado, as exteriores um pouco mais claras, as internas mais longas que as externas, não ultrapassando a altura das flores, glabras em ambas as faces. Capítulos alvos, 5-7 mm diâm. Brácteas florais castanhas, oblanceoladas, $2 \times$ $0,5 \mathrm{~mm}$, ápice acuminado, ciliada, membranácea. Flores 3-meras; ca. 90 por capítulo, 3 vezes mais estaminadas que pistiladas; flores estaminadas 3 $\times 1 \mathrm{~mm}$; pedicelo ca. $1,5 \mathrm{~mm}$ compr.; sépalas 3 $\times 0,5 \mathrm{~mm}$, elípticas a oblanceoladas, castanhas, com pubescência em tufos na porção apical, tricomas longos; corola creme, $2 \times 1 \mathrm{~mm}$; glabra no interior do tubo, estames $2 \mathrm{~mm}$ compr., livres das pétalas, anteras bitecas, tetraesporangiadas, hialinas, pistilódios $0,4 \mathrm{~mm}$ compr; flores pistiladas 2-3 × 1-1,5 mm; sésseis; sépalas 1-2 × 0,5-1 $\mathrm{mm}$, lineares a oblanceoladas, castanhas, com pubescência em tufos na porção apical; pétalas 1,5$2 \times 1 \mathrm{~mm}$, lanceoladas, hialinas, pilosas em ambas as faces, longos tricomas; ramos estigmáticos simples; apêndices (3) nectaríferos, 0,5 mm compr.; estaminódios 3, escamiformes $0,1 \mathrm{~mm}$ compr.

Paepalanthus distichophyllus pode ser facilmente reconhecida pela presença de folhas dísticas, equitantes, marcescentes e cobrindo totalmente o caule, bastante alongado. Quanto à distribuição geográfica, encontra-se restrita aos campos rupestres entre o Planalto de Diamantina e a Serra do Cipó (Ruhland 1903). No PEBI, a espécie foi encontrada sempre em solos arenosos encharcados e em meio a estrato herbáceo denso, que serve de apoio à planta. Foi coletada com flores durante praticamente todos os meses do ano.

Material examinado selecionado: BRASIL. MINAS GERAIS: Diamantina, Parque Estadual do Biribiri, Várzea da Jacuba, 14.I.2011, C.O. Andrino \& I.M. Franco 112 (DIAM); estrada para Biribiri, $7 \mathrm{~km}$ da entrada para Biribiri, 2.V.2001, F.N. Costa \& P.T. Sano 272 (SPF).

14. Paepalanthus eriophaeus Ruhland in Engl., Pflanzenr. 4, Fam. 30: 130. $1903 . \quad$ Fig. 3d

Erva, $12-23 \mathrm{~cm}$ alt., caule aéreo curto, restrito à roseta, até $4 \mathrm{~cm}$ diâm. Folhas planas, persistentes, rosuladas, 4-8 × 0,3-0,6 cm, lanceoladas, agudas, glabrescentes em ambas as faces, margem densamente ciliada. Eixo reprodutivo ausente. Espatas 1-2 cm compr., glabras, membranáceas, ápice truncado, margem irregular e ciliada. Escapos verdes a castanhos, 6-10 cm compr., conjunto de escapos 36-60 por indíviduo, livres entre si, pilosos a pubescentes. Brácteas involucrais creme a castanhas, triangulares, $2-4 \times 2-3 \mathrm{~mm}$, ápice agudo, as interiores um pouco mais claras, as internas mais longas que as externas, não ultrapassando a altura das flores, glabrescentes em ambas as face. Capítulos alvos, 6-8 $\mathrm{mm}$ diâm. Brácteas florais creme a marrom-escuras na porção apical, lanceoladas, $3 \times 0,5 \mathrm{~mm}$, ápice agudo, ciliada, membranácea. Flores 3-meras; ca. 80 por capítulo, 7 vezes mais estaminadas que pistiladas; flores estaminadas $2,5-3,5 \times 1 \mathrm{~mm}$; pedicelo $0,5 \mathrm{~mm}$ compr.; sépalas com $2-3 \times 0,5$ $\mathrm{mm}$, lanceoladas, hialinas a marrom-escuras a partir do terço superior, com pubescência em tufos na porção apical, tricomas curtos; corola hialina, $1-2 \times 0,4 \mathrm{~mm}$; glabra no interior do tubo, estames $1,5 \mathrm{~mm}$ compr., unidos às pétalas, anteras bitecas, tetraesporangiadas, hialinas, pistilódios $0,4 \mathrm{~mm}$ compr; flores pistiladas $2-3 \times 1 \mathrm{~mm}$; sésseis; sépalas $2-3 \times 1 \mathrm{~mm}$, lanceoladas hialinas a marrom-escuras a partir do terço superior,, com tricomas no ápice; pétalas $2-3 \times 1 \mathrm{~mm}$, obovadas ou lanceoladas, com tricomas nas margens e no ápice; ramos estigmáticos bífidos; apêndices (3) nectaríferos, 0,5 mm compr.; estaminódios 3 , escamiformes, $0,1 \mathrm{~mm}$ compr.

Paepalanthus eriophaeus pode ser reconhecida pelo porte mediano, caule sempre curto, restrito às folhas da roseta, folhas bastante ciliadas nas margens e pelos escapos nunca ultrapassando em mais de $3 \mathrm{~cm}$ a altura das folhas, além de múltiplos escapos dispostos linearmente na axila das folhas. A espécie é endêmica da Cadeia do Espinhaço com maior abundância na Serra do Cipó (Ruhland 1903) e na região de Diamantina. Foi coletada com flores em maio, e há registros de coleta em todos os meses do ano em outras localidades.

Material examinado selecionado: BRASIL. MINAS GERAIS: Diamantina, Parque Estadual do Biribiri, Barro Preto, 16.V.2011, C.O. Andrino 162 (DIAM).

15. Paepalanthus flaccidus Kunth, Enum. P1. 3: 511. 1841.

Fig. 3e

Erva, 10-35 cm alt., caule aéreo alongado, decumbente, ramificado, até $15 \mathrm{~cm}$ compr, 2 $\mathrm{mm}$ diâm. Folhas planas, persistentes, dispostas 
ao longo do caule, $0,5-1 \times 0,1 \mathrm{~cm}$, lanceoladas ou lineares, ápice agudo, pilosas em ambas as faces. Eixo reprodutivo ausente. Espatas 1-3 $\mathrm{cm}$ compr., glabrescentes, ápice agudo, margem inteira. Escapos verdes a castanhos, 5-20 cm compr., conjunto de escapos 5-30 por indíviduo, livres entre si, glabrescentes. Brácteas involucrais creme a douradas, lanceoladas a ovadas, $2 \times 0,5$ $\mathrm{mm}$, ápice agudo, as internas mais longas que as externas, não ultrapassando a altura das flores, pubescentes em ambas as faces. Capítulos alvos, 3-5 mm diâm. Brácteas florais, lanceoladas, 1-2 $\times 0,5 \mathrm{~mm}$, ápice agudo a acuminado, glabra, membranácea. Flores 2 -meras; ca. 44 por capítulo, 3 vezes mais estaminadas que pistiladas; flores estaminadas $2 \times 0,5-1 \mathrm{~mm}$; pedicelo $0,5 \mathrm{~mm}$ de compr.; sépalas com $1 \times 0,3 \mathrm{~mm}$, lineares a lanceoladas, castanhas, glabrescentes, tricomas curtos; corola hialina, $1 \times 0,5 \mathrm{~mm}$; glabra no interior do tubo, estames $1 \mathrm{~mm}$ compr., livres das pétalas, anteras bitecas tetraesporangiadas, hialinas, pistilódios $0,2 \mathrm{~mm}$ compr; flores pistiladas $2 \times 0,5-1$; sésseis, sépalas $1 \times 0,2 \mathrm{~mm}$, lineares a lanceoladas, castanhas, glabras; pétalas 1-2 $\times$ $0,5 \mathrm{~mm}$, lanceoladas a obovadas, com tricomas no ápice; ramos estigmáticos bífidos; apêndices (2) nectaríferos, 0,5 mm compr.; estaminódios 2, escamiformes, $0,1 \mathrm{~mm}$ compr.

Paepalanthus flaccidus pode ser reconhecida pelo habito delgado, folhas pequenas, lineares a lanceoladas, membranáceas, distribuídas de maneira uniforme por todo o caule e sem a formação de roseta basal, além das flores dímeras, menos comuns no gênero. A espécie possui distribuição geográfica bastante ampla, ocorrendo nos estados de São Paulo, Goiás, Bahia e, em Minas Gerais, ao longo da Cadeia do Espinhaço, incluindo Serra do Garimpo e Ouro Preto. No PEBI, foi coletada em solos arenosos e úmidos, geralmente associada a gramíneas. Floresce no período chuvoso, entre os meses de outubro a abril.

Material examinado selecionado: BRASIL. MINAS GERAIS: Diamantina, Parque Estadual do Biribiri, estrada Diamantina-Biribiri, $3 \mathrm{~km}$ do trevo de Diamantina, 29.VII.1999, F.N. Costa et al. 58 (SPF); Trilha para o alto da cachoeira da Sentinela, 18.XII.2010, C.O. Andrino et al. 77 (DIAM).

16. Paepalanthus glaziovii Ruhland in Engl., Pflanzenr. 4, Fam. 30: 181. $1903 . \quad$ Fig. 3f

Erva, $20-30 \mathrm{~cm}$ alt., caule aéreo alongado, ramificado dicotomicamente, $20-30 \mathrm{~cm}$ compr.,
2 mm diâm. Folhas planas, decíduas, espiraladas, dispostas ao longo do caule, $2-6 \times 0,2-0,5$ $\mathrm{mm}$, lineares, agudas, espinescentes, glabras a pubescentes em ambas as faces. Eixo reprodutivo ausente. Espatas 2-4 mm compr., glabrescentes, margem ciliada, ápice agudo, margem inteira. Escapos verdes a castanhos, 1,5-2,5 cm compr, livres entre si, glabros. Brácteas involucrais castanhas, ovadas, 1-3 × 1-2 mm, ápice agudo, ciliado, as internas mais longas que as externas, não ultrapassando a altura das flores, glabras em ambas as faces. Capítulos alvos, 3-5 mm diâm. Brácteas florais hialinas a castanhas, lanceoladas, $3 \times 0,5 \mathrm{~mm}$, ápice agudo a arredondado, ciliada, membranácea. Flores 3 -meras; ca. 48 por capítulo, 2 vezes mais estaminadas que pistiladas; flores estaminadas $4 \times 1 \mathrm{~mm}$; pedicelo $1 \mathrm{~mm}$ de compr.; sépalas com $3 \times 0,5 \mathrm{~mm}$, lanceoladas, hialinas, com pubescência em tufos na porção apical, tricomas curtos; corola hialina, $2 \times 0,5 \mathrm{~mm}$; glabras no interior do tubo, estames $2 \mathrm{~mm}$ compr., livres das pétalas, anteras bitecas, tetraesporangiadas, hialinas, pistilódios $1 \mathrm{~mm}$ compr; flores pistiladas 2-3 × 0,5-1 mm; sésseis; sépalas 2-3 × 0,5 mm, lanceoladas, hialinas, com tricomas no ápice; pétalas 2-2,5 ×0,5 mm, oblongas a lanceoladas, com tricomas nas margens e no ápice; ramos estigmáticos bífidos; apêndices (3) nectaríferos, $1 \mathrm{~mm}$ compr.; estaminódios 3 , escamiformes, 0,1 mm compr.

Paepalanthus glaziovii pode ser reconhecida pelo caule alongado ramificado dicotomicamente, folhas lineares, espinescentes e persistentes, dispostas ao longo do caule, e pelos capítulos urceolados. Assemelha-se a $P$. bonsai devido ao caule ramificado e formato dos capítulos, mas diferenciadas pelas folhas persistentes em $P$. glaziovii e restritas ao ápice em $P$. bonsai. É uma espécie rara e microendêmica e não foi encontrada no presente estudo dentro do Parque. Há registro de coleta em abril e, no presente estudo, foi coletada em março. Devido ao pouco volume de material coletado, não é possível inferir um período de floração.

Material adicional examinado: BRASIL. MINAS GERAIS: Diamantina, Estrada para Gouveia, 9.III.2013, C.O. Andrino \& P.T. Sano 244 (SPF).

17. Paepalanthus leucocephalus Ruhland in Engler, Pflanzenr. 13: 199. $1903 . \quad$ Fig. 4a

Erva, 1-2 cm alt., caule aéreo alongado ou curto, restrito à roseta, ramificado, até $4 \mathrm{~cm}$ compr., 


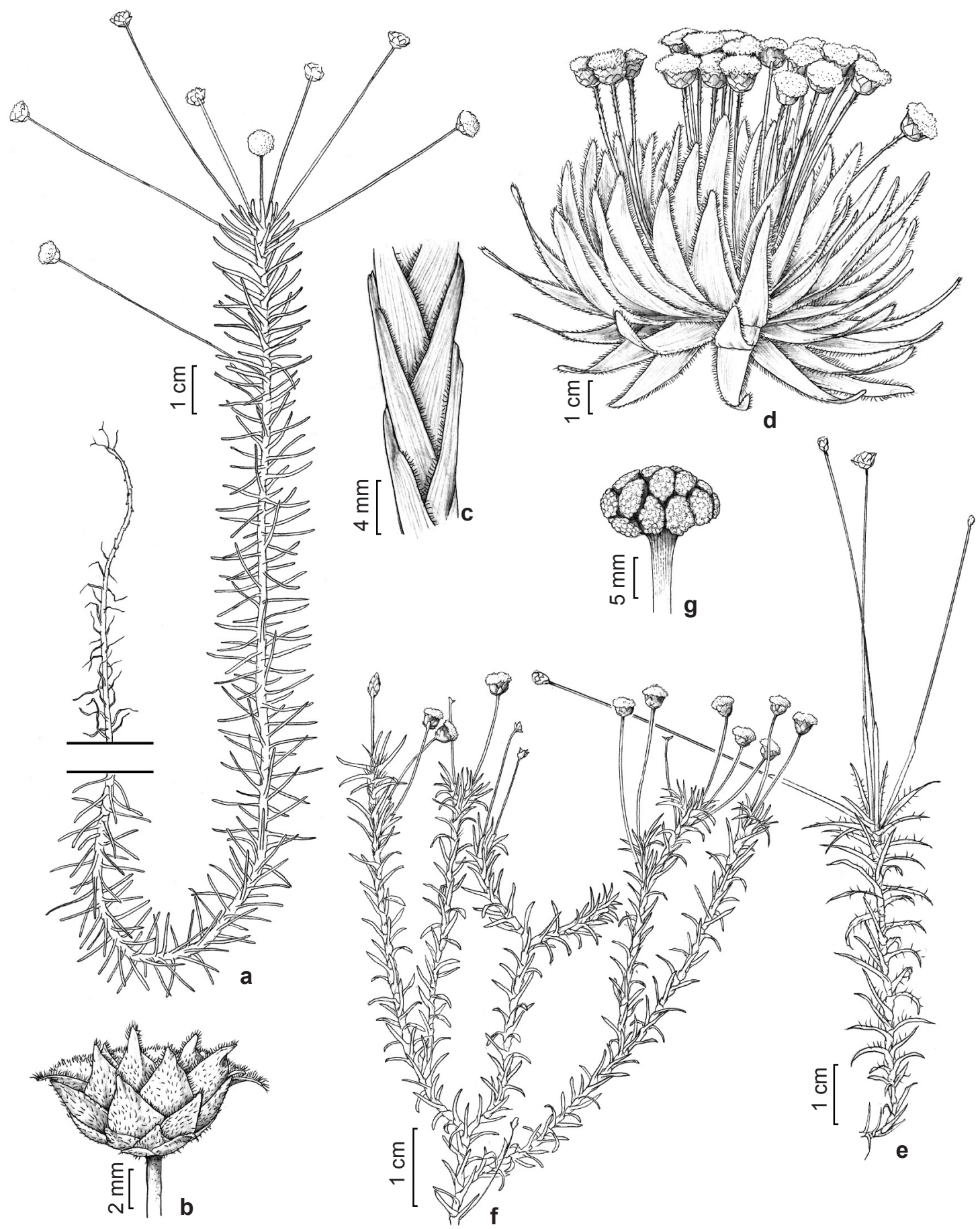

Figura 3 - a. Paepalanthus capillifolius, hábito; b. P. comans, capítulo; c. P. distichophyllus, detalhe das folhas, mostrando filotaxia dística e folhas equitantes; d. Paepalanthus eriophaeus, hábito; e. P. flaccidus, hábito. f. Paepalanthus glaziovii, ramo; g. P.macropodus, capítulo, mostrando união completa dos escapos. (Ilustrado por Marcelo Kubo).

Figure 3 - a. Paepalanthus capillifolius, habit; b. P. comans, capitulum; c. P. distichophyllus, detail of leaves showing phyllotaxis and leaf equitant; d. Paepalanthus eriophaeus, habit; e. P. flaccidus, habit; f. Paepalanthus glaziovii, branch; g. Paepalantthus macropodus, capitulum, showing the complete union of scapes. (Line drawing by Marcelo Kubo). 
$0,2 \mathrm{~cm}$ diâm. Folhas planas, persistentes, rosuladas, 5-10 $\times 0,5 \mathrm{~mm}$, lineares a lanceoladas, agudas, glabrescentes em ambas as faces. Eixo reprodutivo ausente. Espatas ausentes. Escapos ausentes. Brácteas involucrais ausentes. Capítulos alvos, 2-3 $\mathrm{mm}$ diâm. Brácteas florais hialinas, lanceoladas, 1,5 $\times 0,3 \mathrm{~mm}$, ápice acuminado, glabra, membranácea. Flores 2-meras; ca. 20 por capítulo, estaminadas e pistiladas na mesma proporçao; flores estaminadas $0,5 \times 1,5 \mathrm{~mm}$; pedicelo $0,1 \mathrm{~mm}$ de compr.; sépalas com $0,5 \times 0,1 \mathrm{~mm}$, oblanceoladas, hialinas, ápice truncado ciliado; corola hialina, $1 \times 0,5 \mathrm{~mm}$; glabra, estames $0,5 \mathrm{~mm}$ compr., livres das pétalas, anteras bitecas, tetraesporangiadas, hialinas, pistilódios 0,1 mm compr; flores pistiladas $2 \times 0,5 \mathrm{~mm}$; sésseis; sépalas $0,5-1 \times 0,1 \mathrm{~mm}$, lanceoladas, hialinas, glabras; pétalas $0,8 \times 0,1 \mathrm{~mm}$, lanceoladas, ápice truncado ciliado; ramos estigmáticos simples; apêndices (2) nectaríferos, 0,1 mm compr.; estaminódios 2, escamiformes, incospícuos.

Paepalanthus leucocephalus pode ser reconhecida pelo porte bastante reduzido, nunca ultrapassando dois centímetros de comprimento, pela ausência de espatas e escapos e pelas flores dímeras. É morfologicamente muito semelhante a $P$. scleranthus, pertencente ao mesmo subgênero, estas podem ser diferenciadas apenas pela pigmentação do ápice das brácteas florais, ausente em $P$. leucocephalus e enegrecido em $P$. scleranthus. Paepalanthus leucocephalus ocorre na Cadeia do Espinhaço, em Minas Gerais e Bahia (Giulietti et al. 2014), mas devido ao porte bastante reduzido, é possível que seja uma espécie subamostrada, com poucas populações conhecidas até o momento. Foi coletada com flores em maio, e há registros de coleta nos meses de janeiro, abril e agosto.

Material examinado selecionado: BRASIL. MINAS GERAIS: Diamantina, Parque Estadual do Biribiri, estrada para o vilarejo Biribiri, a $6 \mathrm{~km}$ do trevo de Diamantina-Biribiri, 18.VII.2008, L. Echternacht \& T.V. Bastos 1828 (SPF).

18. Paepalanthus macrocephalus Koern. in Mart., Fl. bras. 3(1): 379. 1863.

Erva, 35-52 cm alt., caule aéreo curto, restrito à roseta, até $1 \mathrm{~cm}$ diâm. Folhas planas, persistentes, rosuladas, 3-8 × 0,3-0,6 cm, lanceoladas a oblongas, ápice arredondado, glabrescentes na face abaxial, glabras na face adaxial. Eixo reprodutivo ausente. Paracládios presentes ou não, quando presentes, até $0,5 \mathrm{~cm}$ compr. Espatas 4-9 cm compr., pubescentes a glabras, ápice arredondado a agudo, margem irregular, inteira. Escapos verdes, castanhos a prateados a partir da metade superior, 32-50 cm compr., conjunto de escapos 5-16 por indíviduo, livres entre si, pubescentes na base e seríceos a partir da metade superior. Brácteas involucrais castanhas a marrom-escuras, obovadas, 3-4 × $2 \mathrm{~mm}$, ápice agudo a arredondado, internas e externas de mesmo tamanho, não ultrapassando a altura das flores, pubescentes na face abaxial, pubescentes a glabras na face adaxial, margem ciliada. Capítulos alvos, 0,8-1,6 mm diâm. Brácteas florais hialinas, lineares a espatuladas, $3 \times 0,5 \mathrm{~mm}$, ápice agudo a acuminado, ciliada, membranácea. Flores 3-meras; ca. 220 por capítulo, 3 vezes mais estaminadas que pistiladas; flores estaminadas $3 \times 2 \mathrm{~mm}$; pedicelo $0,5 \mathrm{~mm}$ compr.; sépalas com $3 \times 0,5$ $\mathrm{mm}$, elípticas a oblanceoladas, hialinas, ciliadas, corola $2,5 \times 1 \mathrm{~mm}$; glabra no interior do tubo, estames $2 \mathrm{~mm}$ compr., livres das pétalas, anteras bitecas, tetraesporangiadas, hialinas, pistilódios $0,5 \mathrm{~mm}$ compr; flores pistiladas $2-3 \times 1-1,5$ mm; sésseis; sépalas $2 \times 0,8-1 \mathrm{~mm}$, elípticas, hialinas, com tricomas no ápice; pétalas $2 \times 0,5$ $\mathrm{mm}$, lanceoladas, com tricomas nas margens e no ápice; ramos estigmáticos bífidos; apêndices (3) nectaríferos, 1,2 mm compr; estaminódios 3, escamiformes, 0,3 mm compr.

Paepalanthus macrocephalus é uma espécie com variação morfológica ampla e muitas variedades descritas, além de prováveis sinônimos, sendo imprescindível um estudo mais aprofundado para sua correta circunscrição. Pode ser reconhecida pela combinação de algumas características, tais como folhas cartáceas glabrescentes com ápice arredondado, escapos com pilosidade serícea a partir da metade superior, conferindo uma coloração prateada a estes e receptáculo marrom-escuro glabrescente. No entanto, esse padrão apresenta diversas variações ao longo da distribuição da espécie. É restrita à porção mineira da Cadeia do Espinhaço, ocorrendo numerosas populações da Serra do Cipó a Serra do Cabra. Foram coletados espécimes com flores entre os meses de fevereiro e outubro. É uma das sempre-vivas comercializadas na região de Diamantina, conhecida popularmente por "botão branco".

Material examinado selecionado: BRASIL. MINAS GERAIS: Diamantina, Parque Estadual do Biribiri, estrada Diamantina-Biribiri a $3 \mathrm{~km}$ do trevo de Diamantina, 29.VII.1999, F.N. Costa et al. 55 (SPF); Barris, 12.I.2011, C.O. Andrino \& I.M. Franco 103 (DIAM); Campo São Miguel, 20.V.2011, C.O. Andrino 173 (DIAM). 
19. Paepalanthus macropodus Ruhland in Engl.,Pflanzenr. 4, Fam. 30: 212. $1903 . \quad$ Fig. 3g

Erva, 30-220 cm alt., caule aéreo alongado, 10-200 cm compr, 1-5 cm diâm. Folhas planas, persistentes, espiraladas, 6-26 × 1-2,5 cm, lanceoladas, agudas, glabrescentes em ambas as faces. Eixo reprodutivo ausente. Espatas 1,4-6,5 cm compr., glabrescentes, ápice truncado, margem inteira ciliada. Escapos verdes, $24-58 \mathrm{~cm}$ compr., conjunto de escapos 4-13 por indíviduo completamente unidos, 7-15 capítulos por escapo, glabrescentes. Brácteas involucrais marrom escuras, ovadas, 1,5-2,5 × 1-2 mm, ápice agudo, enegrecidas na porção distal, não ultrapassando a altura das flores, glabrescentes em ambas as faces, com tufos de tricomas no ápice. Capítulos alvos, 5-7 mm diâm., conjunto de capítulos 10-20 $\mathrm{mm}$ diâm. Brácteas florais creme a enegrecidas no ápice, obovadas, $2 \times 1,5 \mathrm{~mm}$, ápice agudo a acuminado, ciliada, membranácea. Flores 3-meras; ca. 28 por capítulo, 3 vezes mais estaminadas que pistiladas; flores estaminadas $2 \times 1 \mathrm{~mm}$; pedicelo $0,8 \mathrm{~mm}$ compr.; sépalas com $1,5 \times 0,5 \mathrm{~mm}$, elípticas a oblanceoladas, castanhas a marromescuras na porção distal, com pubescência em tufos na porção apical, tricomas curtos; corola creme, 1,5 $\times 0,5 \mathrm{~mm}$; glabra no interior do tubo, estames $1 \mathrm{~mm}$ compr., livres das pétalas, anteras bitecas tetraesporangiadas, creme, pistilódios 0,4 $\mathrm{mm}$ compr; flores pistiladas $2-2,5 \times 1,5-2 \mathrm{~mm}$; pedicelo $0,5 \mathrm{~mm}$; sépalas $2-2,5 \times 1-1,5 \mathrm{~mm}$, obtruladas, hialinas, com tricomas no ápice; pétalas $2-2,5 \times 1,5 \mathrm{~mm}$, lanceoladas a obtruladas, tricomas nas margens e no ápice; ramos estigmáticos bífidos; apêndices (3) nectaríferos, 0,5 mm compr.; estaminódios 3, escamiformes $0,2 \mathrm{~mm}$ compr.

Paepalanthus macropodus possui escapos completamente unidos até o ápice, sendo às vezes constatada apenas pela visualização das brácteas involucrais na inflorescência. Pode ser facilmente reconhecida por ser a única espécie desse subgênero na área de estudo com o caule alongado, atingindo até $2 \mathrm{~m}$ altura. A espécie é ocorre em Minas Gerais, na Serra do Brigadeiro, e na Cadeia do Espinhaço, de Ouro Preto até o Planalto de Diamantina (TissotSquali 1997). Foi coletada com flores nos meses de julho a novembro.

Material examinado selecionado: BRASIL. MINAS GERAIS: Diamantina, Parque Estadual do Biribiri, trilha para o alto da cachoeira da Sentinela, 18.XI.2010, C.O. Andrino et al. 76 (DIAM); idem, 1.VI.2011, C.O. Andrino \& M.M. Cota 176 (DIAM).
20. Paepalanthus pedunculatus Ruhland in Engl., Pflanzenr. 4, Fam. 30: 146. 1903.

Erva, 20-40 cm alt., caule aéreo curto, restrito à roseta, até $2 \mathrm{~cm}$ diâm. Folhas planas, persistentes, rosuladas, 2,5-6 $\times 0,3-2 \mathrm{~cm}$, oblongas a lanceoladas, ápice agudo a arredondado, glabrescentes em ambas as faces. Eixo reprodutivo ausente. Espatas 6,5-9.5 cm compr., glabras, ápice arredondado a agudo, margem irregular. Escapos verdes a castanhos, $21-38 \mathrm{~cm}$ compr., conjunto de escapos 5-12 por indíviduo, livres entre si, glabros. Brácteas involucrais castanho-escuras, triangulares, 5-11 ×2-6 mm, ápice agudo, internas e externas do mesmo tamanho, não ultrapassando a altura das flores, glabras, ciliadas. Capítulos alvos, 5-18 mm diâm. Brácteas florais hialinas, lanceoladas, $4 \times 0,5 \mathrm{~mm}$, ápice agudo a acuminado, ciliada, membranosa. Flores 3-meras; ca. 114 por capítulo, 2 vezes mais estaminadas que pistiladas; flores estaminadas $4 \times 2 \mathrm{~mm}$; pedicelo $1,2 \mathrm{~mm}$ de compr.; sépalas com $3 \times 0,5 \mathrm{~mm}$, elípticas a oblanceoladas, hialinas, com pubescência em tufos na porção apical, tricomas curtos; corola hialina, $3,5 \times 1 \mathrm{~mm}$; pilosa no interior do tubo, estames $3 \mathrm{~mm}$ compr., livres das pétalas, anteras bitecas, tetraesporangiadas, hialinas, pistilódios $0,4 \mathrm{~mm}$ compr; flores pistiladas 4-6 × 1,5-2 mm; sésseis; sépalas 3,5-5 × 0,8-1 mm, obovadas, hialinas, com tricomas no ápice; pétalas 3-4,5 $\times$ $1,5 \mathrm{~mm}$, lanceoladas, com tricomas nas margens e no ápice; ramos estigmáticos bífidos; apêndices (3) nectaríferos, 1,5 mm compr.; estaminódios 3, escamiformes $0,3 \mathrm{~mm}$ compr.

Neste tratamento, Paepalanthus pedunculatus foi definido pelo caule curto restrito à roseta, e pelos escapos e brácteas involucrais glabrescentes. Essas características permitem diferenciar $P$. pedunculatus de algumas espécies semelhantes morfologicamente tratadas neste estudo, como P. macrocephalus e P. subfalcatus, que possuem escapos com pilosidade serícea e receptáculo viloso, respectivamente. Porém, existe grande variação morfológica entre os indivíduos e um melhor estudo poderá revelar se tratam-se despécies distintas. Até o momento, o que foi possivel de ser feito foi reuni-las sob esse único nome, sabendo que existe tal variacao. Paepalanthus pedunculatus possui distribuição restrita ao estado de Minas Gerais, ocorrendo na Serra da Canastra, Serra do Cipó, Planalto de Diamantina e Grão-Mogol (Sano et al. 2010) Há registros de coleta em todos os meses do ano e, bem distribuídas, sugerindo que a espécie floresce igualmente em todas as estações. 
Material examinado selecionado: BRASIL. MINAS GERAIS: Diamantina, Parque Estadual do Biribiri, estrada Diamantina-Biribiri, $6 \mathrm{~km}$ depois de Diamantina, 19.VIII.1994, S. Splett 508 (SPF); subida para Boa Vista, próximo ao rio Biribiri e à entrada da vila Biribiri, 16.VII.2008, L. Echternacht \& T.V. Bastos 1816 (BHCB); estrada para Biribiri a $5 \mathrm{~km}$ da rodovia BR 259, 20.VIII.1990, R. Mello-Silva et al. 349 (SPF).

\section{Paepalanthus planifolius Koern.in Mart, Fl.} bras. 3(1): 413. 1863.

Erva, 30-54 $\mathrm{cm}$ alt., caule curto, restrito à roseta, até $2 \mathrm{~cm}$ compr., até $1,5 \mathrm{~cm}$ diâm. Folhas planas, persistentes, rosuladas, 5-38 × $1-2 \mathrm{~cm}$, lanceoladas, agudas, pubescentes em ambas as faces. Eixo reprodutivo ausente. Espatas 9-20 cm compr., glabrescentes, ápice truncado, margem inteira. Escapos verdes, $26-51 \mathrm{~cm}$ compr., conjunto de escapos 8-36 por indíviduo, completamente unidos, 11-40 capítulos por escapo, glabrescentes. Brácteas involucrais marrom-escuras a enegrecidas, ovadas, 2-3 × 1,5-2 mm, ápice agudo, as interiores um pouco mais escuras, as internas e externas do mesmo tamanho, não ultrapassando a altura das flores, glabrescente em ambas as faces. Capítulos alvos a enegrecidos, 2-4 mm diâm, conjunto de capítulos ca. $1,5 \mathrm{~cm}$ de diâm. Brácteas florais castanhas, oblongas a lanceoladas, $2-3 \times 0,5-1$ $\mathrm{mm}$, ápice acuminado, ciliada, membranácea. Flores 3-meras; ca. 52 por capítulo, 4 vezes mais estaminadas que pistiladas; flores estaminadas 2 $\times 1 \mathrm{~mm}$; pedicelo $0,3 \mathrm{~mm}$ de compr.; sépalas $2 \times$ $0,8 \mathrm{~mm}$, obovadas, castanhas, com pubescência em tufos na porção apical, tricomas curtos; corola creme, $1 \times 0,5 \mathrm{~mm}$; glabra no interior do tubo, estames 1,5 mm compr., livres das pétalas, anteras bitecas, tetraesporangiadas, creme a castanhoescuras, pistilódios $0,5 \mathrm{~mm}$ compr; flores pistiladas 2-4 $\times 1 \mathrm{~mm}$; pedicelo $0,5 \mathrm{~mm}$; sépalas $2-3 \times 0,8-1$ $\mathrm{mm}$, obtruladas, castanhas, com tricomas no ápice; pétalas $2-3 \times 0,5 \mathrm{~mm}$, ovadas, com tricomas nas margens e no ápice; ramos estigmáticos bífidos; apêndices (3) nectaríferos, 0,5 mm compr.; estaminódios 3, escamiformes, $0,2 \mathrm{~mm}$ compr.

Paepalanthus planifolius pode ser distinguida das demais espécies pela união dos escapos até a base do capítulo e pelo caule curto, restrito à roseta. Dentre as espécies do subgênero ao qual pertence, $P$. subg. Platycaulon, assemelha-se a P. macropodus, podendo ser diferenciada pelo caule curto, ao passo que $P$. macropodus possui caule alongado. Paepalanthus planifolius possui distribuição ampla, ocorrendo nos estados do Rio
Grande do Sul, Santa Catarina, Paraná, São Paulo, Minas Gerais, Rio de Janeiro, Espírito Santo e no Distrito Federal (Tissot-Squali 1997). Foi coletado com flores durante o período seco, em julho, mas há registros de coleta durante todo o ano.

Material examinado selecionado: BRASIL. MINAS GERAIS: Diamantina, Parque Estadual do Biribiri, Estrada: Biribiri, ca. $10 \mathrm{~km}$ de Diamantina, 19.VII.1987, J.R. Pirani et al. CFCR 11111 (SPF).

22. Paepalanthus polygonus Koern.in Mart., Fl. bras. 3(1): 393. 1863.

Erva, 90-150 cm alt., caule aéreo alongado, bastante ramificado na porção apical, 90 a $150 \mathrm{~cm}$ compr., até $10 \mathrm{~cm}$ diâm. Folhas planas, persistentes, espiraladas, 7-37 × 0,5-1,1 cm, triangulares, base amplexicaule, agudas, glabrecentes em ambas as faces. Eixo reprodutivo ausente. Espatas 0,6-1 cm compr., glabras, ápice truncado, margem irregular. Escapos verdes, 4-5 cm compr., conjunto de escapos 30-60 por ramo por floração, livres entre si, conjunto de 4-10 escapos emergindo da mesma axila foliar, glabrescentes. Brácteas involucrais douradas, largamente ovadas, 3-4 × 2-3 mm, ápice acuminado, as interiores um pouco mais claras, as internas mais longas que as externas, não ultrapassando a altura das flores, glabrescentes em ambas as faces, margem ciliada. Capítulos alvos, 3-5 mm diâm. Brácteas florais castanhas, lineares a lanceoladas, $3 \times 0,5 \mathrm{~mm}$, ápice agudo, ciliada, membranácea. Flores 3 -meras; ca. 24 por capítulo, 2 vezes mais estaminadas que pistiladas; 5 vezes mais estaminadas que pistiladas; flores estaminadas $3 \times 1 \mathrm{~mm}$; pedicelo $0,3 \mathrm{~mm}$ compr.; sépalas com $3 \times 0,5 \mathrm{~mm}$, elípticas, hialinas, com pubescência em tufos na porção apical, tricomas curtos; corola creme, $0,5 \times 0,3 \mathrm{~mm}$; glabra no interior do tubo, estames $2 \mathrm{~mm}$ compr., livres das pétalas, anteras bitecas, tetraesporangiadas, creme, pistilódios 0,2 $\mathrm{mm}$ compr; flores pistiladas $3 \times 1,5 \mathrm{~mm}$; pedicelo $0,3 \mathrm{~mm}$ compr.; sépalas $3 \times 0,5 \mathrm{~mm}$, oblanceoladas, creme a castanhas, com tricomas no ápice; pétalas $3 \times 0,5 \mathrm{~mm}$, oblongas, com tricomas nas margens e no ápice; ramos estigmáticos bífidos; apêndices (3) nectaríferos, $1 \mathrm{~mm}$ compr.; estaminódios 3, escamiformes, 0,1 mm compr.

Paepalanthus polygonus é bastante confundida com espécies do gênero Actinocephalus por possuir hábito robusto e caule espesso, lenhoso e bastante ramificado na porção apical, que lembram os paracládios dessas espécies. Porém, pode ser distinguida principalmente pelos escapos que emergem da axila foliar. Paepalanthus 
polygonus apresenta também folhas triangulares, espiraladas, amplexicaules, distribuídas por todo o caule, sendo este coberto pela bainha de folhas velhas na porção basal, além de ramos estigmáticos bífidos. A espécie é endêmica do Planalto de Diamantina e floresce durante todos os meses do ano.

Material examinado selecionado: BRASIL. MINAS GERAIS: Diamantina, Parque Estadual do Biribiri, trilha para a cachoeira da Sentinela, 18.XI.2010, C.O. Andrino et al. 80 (DIAM).

23. Paepalanthus pubescens Koern. in Mart., Fl. bras. 3(1): 384. 1863.

Fig. 4b

Erva, 13-26 cm alt., caule aéreo curto, restrito à roseta, até $2 \mathrm{~cm}$ diâm. Folhas planas, persistentes, rosuladas, $2-3 \times 0,3-2 \mathrm{~cm}$, oblongas a lanceoladas, ápice agudo a arredondado, pilosas em ambas as faces. Eixo reprodutivo ausente. Espatas 2-4 cm compr., pilosas, ápice arredondado a agudo, margem inteira. Escapos verdes a castanhos, 15-24 cm compr., conjunto de escapos 5-12 por indíviduo, livres entre si, glabros. Brácteas involucrais castanhas, triangulares, 5-11 $\times 2-6$ $\mathrm{mm}$, ápice agudo, as internas e externas do mesmo tamanho, não ultrapassando a altura das flores, glabras, ciliadas. Capítulos alvos, 5-18 mm diâm. Brácteas florais hialinas, lanceoladas, $4 \times 0,5 \mathrm{~mm}$, ápice agudo a acuminado, ciliada, membranosa. Flores 3-meras; ca. 74 por capítulo, 4 vezes mais estaminadas que pistiladas; flores estaminadas $3 \times$ $2 \mathrm{~mm}$; pedicelo 1,2 $\mathrm{mm}$ compr.; sépalas com $3 \times$ $0,5 \mathrm{~mm}$, elípticas a oblanceoladas, hialinas, com pubescência em tufos na porção apical, tricomas curtos; corola hialina, $3,5 \times 1 \mathrm{~mm}$; pilosa no interior do tubo, estames $3 \mathrm{~mm}$ compr., livres das pétalas, anteras bitecas, tetraesporangiadas, hialinas, pistilódios $0,4 \mathrm{~mm}$ compr; flores pistiladas $4-6$ $\times 1,5-2 \mathrm{~mm}$; sésseis; sépalas 3,5-5 × 0,8-1 mm, obovadas, hialinas, com tricomas no ápice; pétalas 3-4,5 $\times 1,5 \mathrm{~mm}$, lanceoladas, com tricomas nas margens e no ápice; ramos estigmáticos bífidos; apêndices (3) nectaríferos, 1,5 mm compr.; estaminódios 3, escamiformes, $0,3 \mathrm{~mm}$ compr.

Paepalanthus pubescens pertence a $P$. ser. Paepalanthus e, como muitas espécies desse grupo é de difícil determinação e circunscrição. Dentre as espécies de Paepalanthus do PEBI, pode ser reconhecida pelo hábito delgado, caule curto, restrito à roseta, folhas membranáceas, pilosas em ambas as faces, e espatas e escapos pilosos. Há registros em Minas Gerais. Habita solos arenosos em campos rupestres. Foi coletada com flores de junho a novembro.
Material examinado selecionado: BRASIL. MINAS GERAIS: Diamantina, Parque Estadual do Biribiri, Lapa do Forno, 16.V.2011, C.O. Andrino et al. 165 (DIAM, SPF).

24. Paepalanthus regelianus Koern. in Mart., Fl. bras. 3(1): 386. 1863.

Erva, 30-45 cm alt., caule aéreo curto, restrito à roseta, até $3 \mathrm{~cm}$ diâm. Folhas planas, persistentes, rosuladas, $15-26 \times 1,3-1,5 \mathrm{~cm}$, lanceoladas, agudas, pilosas na face abaxial, glabras a glabrescentes na face adaxial. Eixo reprodutivo ausente. Espatas 8-13 cm compr., glabrescentes, ápice agudo, margem inteira. Escapos castanhos a marrom-escuros, 36-45 cm compr., conjunto de escapos 26-35 por indíviduo, livres entre si, pilosos na metade inferior, glabrescentes na metade superior. Brácteas involucrais marrom-escuras, triangulares, 3-4 × 2-3 mm, ápice agudo a obtuso, as interiores um pouco mais escuras, as internas mais longas que as externas, não ultrapassando a altura das flores, glabrescentes em ambas as faces, ciliadas. Capítulos alvos, 12-20 mm diâm. Brácteas florais hialinas a castanhas no ápice, lanceoladas, 4 $\times 0,5 \mathrm{~mm}$, ápice agudo a acuminado, membranácea. Flores 3-meras; ca. 362 por capítulo, 4 vezes mais estaminadas que pistiladas; flores estaminadas 4 $\times 2 \mathrm{~mm}$; pedicelo $0,5 \mathrm{~mm}$ de compr.; sépalas com $3 \times 0,5 \mathrm{~mm}$, lanceoladas a obtruladas, hialinas a castanhas no ápice; corola hialina, $2 \times 1 \mathrm{~mm}$; glabra no interior do tubo, estames $3 \mathrm{~mm}$ compr., livres das pétalas, anteras bitecas tetraesporangiadas, hialinas, pistilódios $1 \mathrm{~mm}$ compr.; flores pistiladas $4-5 \times$ 1-1,5 mm; sésseis; sépalas 4,5-5 × 0,8-1 mm, lanceoladas a obtruladas, hialinas a castanhas, com tricomas no ápice; pétalas $3 \times 1 \mathrm{~mm}$, lanceoladas a espatuladas, com tricomas nas margens e no ápice; ramos estigmáticos bífidos; apêndices (3) nectaríferos, 1,5 mm compr.; estaminódios 3, escamiformes $0,3 \mathrm{~mm}$ compr.

Paepalanthus regelianus pode ser reconhecida pela roseta robusta, folhas largamente lanceoladas, pilosas na face abaxial e glabrescentes na face adaxial, escapos glabrescentes e castanhos a marrom-escuros. Conhecida até então por poucas coleções de uma única localidade no município de Serro sendo registrada pela primeira vez no Parque, em população com poucos indivíduos. Foi coletada com flores em final de antese em maio, sugerindo um período de floração no fim do período de chuvas. Material examinado selecionado: BRASIL. MINAS GERAIS: Diamantina, Parque Estadual do Biribiri, Alto da Jacuba, 16.V.2011, C.O. Andrino 154 (DIAM). 
25. Paepalanthus ruficeps Ruhlandin Engler, Pflanzenr. 4, Fam. 30: 146. $1903 . \quad$ Fig. 4c-d Erva, $40-50 \mathrm{~cm}$ alt., caule aéreo curto, até $2 \mathrm{~cm}$ compr, $1 \mathrm{~cm}$ diâm. Folhas conduplicadas, persistentes, dísticas, $5-18 \times 0,3-0,5 \mathrm{~cm}$, lanceoladas, agudas, glabrescentes em ambas as faces. Eixo reprodutivo ausente. Espatas 14-22 cm compr., glabras, ápice agudo, margem inteira. Escapos verdes a castanhos, 4,5-37 cm compr., conjunto de escapos 1-2 por indíviduo, livres entre si, glabros. Brácteas involucrais catanhas, triangulares, $3-7 \times 1-3 \mathrm{~mm}$, ápice agudo, as internas mais longas que as externas, não ultrapassando a altura das flores, pilosas na face abaxial, glabras na face adaxial. Capítulos amarelos, 10-22 mm diâm. Brácteas florais creme, lanceoladas, 4-5 × 0,5-1 $\mathrm{mm}$, ápice agudo a obtuso, glabras, membranáceas. Flores 3-meras; ca. 160 por capítulo, 4 vezes mais estaminadas que pistiladas; flores estaminadas 3-5 $\times 1-2 \mathrm{~mm}$; pedicelo $0,2 \mathrm{~mm}$ de compr.; sépalas com $4 \times 1 \mathrm{~mm}$, lanceoladas, hialinas, com pubescência em tufos na porção apical; corola hialina, 3-4 × $1 \mathrm{~mm}$; glabra, estames $3 \mathrm{~mm}$ compr., livres das pétalas, anteras bitecas tetraesporangiadas, creme a castanho-escuras, pistilódios $0,5 \mathrm{~mm}$ compr; flores pistiladas 4-6 × 1,5-2 mm; sésseis; sépalas 4-5 $\times 0,5-1 \mathrm{~mm}$, lanceoladas, hialinas, com tricomas no ápice; pétalas $3-4,5 \times 1,5 \mathrm{~mm}$, lanceoladas, com tricomas nas margens e no ápice; ramos estigmáticos bífidos; apêndices (3) nectaríferos, $0,5 \mathrm{~mm}$ compr.; estaminódios 3 , escamiformes, $0,1 \mathrm{~mm}$ compr.

Paepalanthus ruficeps pode ser facilmente distinguida pelos capítulos amarelos, sendo a única espécie do Parque com essa característica. Além disso, possui as folhas conduplicadas e dísticas. A espécie é endêmica do Planalto de Diamantina, muito abundante em Diamantina e Gouvêia. Habita solos arenosos quartizíticos. Floresce de abril a setembro.

Material examinado selecionado: BRASIL. MINAS GERAIS: Diamantina, Parque Estadual do Biribiri, Barro Preto, 16.V.2011, C.O. Andrino 158 (DIAM); Lapa do Forno, 19.V.2011, C.O. Andrino 166 (DIAM).

26. Paepalanthus rufo-albus Silveira, Floral. Mont.: 94. 1928.

Erva, 7-15 cm alt., formando touceiras, caule aéreo alongado, ramificado na porção basal e apical, 2 a 7 cm compr., até $5 \mathrm{~mm}$ diâm, coberto pela bainha de folhas velhas. Folhas planas, persistentes, espiraladas, 5-20 × 1-2 mm, lanceoladas, agudas a obtusas, pubescentes em ambas as faces. Eixo reprodutivo ausente. Espatas 1-2 cm compr., pubescentes, ápice agudo, margem inteira e ciliada. Escapos verdes a castanhos, conjunto de escapos 2-3 por ramo, livres entre si, pubescentes. Brácteas involucrais castanhas a douradas, triangulares, 1-2 $\times 1 \mathrm{~mm}$, ápice agudo, as internas mais longas que as externas, não ultrapassando a altura das flores, glabrescentes em ambas as faces. Capítulos alvos, 4-6 mm diâm. Brácteas florais hialinas, ovadas, 1,5 ×0,5 mm, ápice arredondado, ciliada, membranácea. Flores 3-meras; ca. 89 por capítulo, 6 vezes mais estaminadas que pistiladas; flores estaminadas $1,5-2 \times 1 \mathrm{~mm}$; pedicelo $0,3 \mathrm{~mm}$ compr.; sépalas com 1,2-1,7 ×0,5 mm, elípticas a obovadas, hialinas, com pubescência em tufos na porção apical; corola hialina, 1,2-1,5 × 0,5 $\mathrm{mm}$; glabras no interior do tubo, estames 0,5 $\mathrm{mm}$ compr., livres das pétalas, anteras bitecas, tetraesporangiadas, castanhas, pistilódios $0,2 \mathrm{~mm}$ compr.; flores pistiladas $1-2 \times 0,5 \mathrm{~mm}$; pedicelo 0,2 $\mathrm{mm}$; sépalas 1,2-1,5 ×0,4 mm, oblongas a ovadas, hialinas, com tricomas no ápice; pétalas $1-1,5$ $\times 0,5 \mathrm{~mm}$, oblongas a obovadas, com tricomas no ápice; ramos estigmáticos bífidos; apêndices (3) nectaríferos, 0,5 mm compr.; estaminódios 3, escamiformes, $0,1 \mathrm{~mm}$ compr.

Paepalanthus rufo-albus pode ser reconhecida pela formação de touceiras, caule alongado bastante ramificado, coberto por bainha de folhas velhas e pelas folhas lanceoladas e restritas ao ápice caulinar. É conhecida por poucos materiais, restrita ao Planalto de Diamantina, mais precisamente ao município de Diamantina. Habita solos arenosos entre afloramentos rochosos. Foi coletada com flores de março a setembro, a sudeste do PEBI.

Material examinado selecionado: BRASIL. MINAS GERAIS: Diamantina, Parque Estadual do Biribiri, Lapa do Forno, 19.V.2011, C.O. Andrino 168 (DIAM).

27. Paepalanthus scirpeus Mart. ex Koern. in Mart., Fl. bras. 3(1): 364. 1863.

Erva, 8-10 cm alt., caule aéreo curto, restrito à roseta, $2 \mathrm{~mm}$ diâm. Folhas planas, decíduas, rosuladas, $1-1,5 \times 0,1 \mathrm{~cm}$, lineares, agudas, pubescentes a glabras em ambas as faces. Eixo reprodutivo ausente. Espatas 0,6-1 cm compr., pubescentes a glabras, ápice truncado a agudo, margem inteira ou irregular. Escapos verdes, 6-10 cm compr., conjunto de escapos 6-70 por indíviduo, livres entre si, glabrescentes. Brácteas involucrais 
marrom escuras, obovadas a obtruladas, 0,5-1 $\times$ $0,5 \mathrm{~mm}$, ápice arredondado a obtuso, as internas mais longas que as externas, não ultrapassando a altura das flores, ciliadas, glabras em ambas as faces. Capítulos alvos, ca. $2 \mathrm{~mm}$ diâm. Brácteas florais hialinas ou castanhas, obovadas, $1 \times 0,5$ $\mathrm{mm}$, ápice obtuso, ciliadas ou não, membranáceas. Flores 3-meras; ca. 28 por capítulo, 3 vezes mais estaminadas que pistiladas; flores estaminadas ca. $1 \mathrm{~mm}$; pedicelo $0,2 \mathrm{~mm}$ compr.; sépalas com $0,7 \times 0,3 \mathrm{~mm}$, obovadas a espatuladas, hialinas a marrom-escuras na porção distal, com pubescência em tufos na porção apical, tricomas curtos; corola hialina a castanha, $0,5 \times 0,3 \mathrm{~mm}$; glabra no interior do tubo, estames $0,4 \mathrm{~mm}$ compr., livres das pétalas, anteras bitecas, biesporangiadas, hialinas, pistilódios 0,2 mm compr.; flores pistiladas $1 \times$ $0,5 \mathrm{~mm}$; sésseis; sépalas $0,7 \times 0,5 \mathrm{~mm}$, obovadas, hialinas a castanhas, com tricomas no ápice; pétalas $0,3 \times 0,5 \mathrm{~mm}$, obovadas a espatuladas, hialinas, com tricomas no ápice; ramos estigmáticos bífidos; apêndices (2) nectaríferos, 0,2 mm compr.; estaminódios 2, escamiformes, 0,1 mm compr.

Paepalanthus scirpeus são ervas muito delicadas, com caule extremamente reduzido, sendo visíveis apenas os escapos, já que as folhas são decíduas e pouco numerosas. Os indivíduos de $P$. scirpeus podem também ser distinguidos pelas anteras monotecas. É endêmica da porção mineira da Cadeia do Espinhaco (Ruhland 1903). Habita solos arenosos em fendas de rochas. Foi encontrada com flores durante todo o ano.

Material examinado selecionado: BRASIL. MINAS GERAIS: Diamantina, Parque Estadual do Biribiri, Lapa do Forno, 19.V.2011, C.O. Andrino 169 (DIAM); 25.II.1975, G. Hatschbach 36485 (MBM).

28. Paepalanthus sphaerocephalus Ruhland in Engl., Pflanzenr. 4, Fam. 30: 182. 1903.

Erva, 12-15 cm alt., caule aéreo curto, restrito à roseta, 0,2 cm diâm. Folhas planas, persistentes, rosuladas, $0,5 \times 1 \mathrm{~cm}$, lineares, ápice arredondado, glabras em ambas as faces. Eixo reprodutivo ausente. Espatas 0,7-1,2 cm compr., glabras, ápice truncado, margem irregular. Escapos verdes a castanhos, 8-13 cm compr., conjunto de escapos 1-3 por indíviduo, livres entre si, pilosos. Brácteas involucrais castanho-escuras, triangulares a lanceoladas, 2-3×1 mm, ápice agudo a obtuso, as internas mais longas que as externas, não ultrapassando a altura das flores, pubescentes externamente. Capítulos alvos, 0,3-0,6 mm diâm.
Brácteas florais castanhas na porção mediana, obovada, $2 \times 1 \mathrm{~mm}$, ápice acuminado, glabra, membranácea. Flores 2-meras; ca. 60 por capítulo, 4 vezes mais estaminadas que pistiladas; flores estaminadas $2 \times 0,5 \mathrm{~mm}$; pedicelo $0,2 \mathrm{~mm}$ compr.; sépalas com $2 \times 0,5 \mathrm{~mm}$, oblanceoladas, hialinas, glabras; corola hialina, $1,5 \times 0,3 \mathrm{~mm}$; glabra no interior do tubo, estames $1 \mathrm{~mm}$ compr., livres das pétalas, anteras bitecas, tetraesporangiadas, hialinas, pistilódios $0,2 \mathrm{~mm}$ compr; flores pistiladas $2 \times 1 \mathrm{~mm}$; sésseis; sépalas $2 \times 0,5 \mathrm{~mm}$, oblongas, hialinas, glabras; pétalas $1 \times 0,3 \mathrm{~mm}$, oblongas a oblancealada, glabras; ramos estigmáticos bífidos; apêndices (2) nectaríferos, 0,2 mm compr.; estaminódios 2, escamiformes, 0,2 mm compr.

Paepalanthus sphaerocephalus pode ser reconhecida pelo hábito agregado, folhas diminutas em rosetas basais, longos escapos pilosos e pelo receptáculo plano. Ocorre em toda a Cadeia do Espinhaço, em Minas Gerais e Bahia (Ruhland 1903) Há registros de coleta nos meses de maio a agosto. Habita solos arenosos, geralmente em beira de trilhas.

Material examinado selecionado: BRASIL. MINAS GERAIS: Diamantina, Parque Estadual do Biribiri, Barro Preto, 16.V.2011, C.O. Andrino 159 (DIAM).

29. Paepalanthus subfalcatus Ruhland in Engl., Pflanzenr. 4, Fam. 30: 151. 1903.

Erva, 20-35 cm alt., caule aéreo curto, restrito à roseta, até $2 \mathrm{~cm}$ diâm. Folhas planas, persistentes, rosuladas, 3-6 × $1 \mathrm{~cm}$, lanceoladas, ápice agudo a acuminado, glabrescentes em ambas as faces. Eixo reprodutivo ausente. Espatas 6,5-8 cm compr., glabras, ápice arredondado a agudo, margem irregular. Escapos castanhos, 20-32 cm compr., conjunto de escapos 3-9 por indíviduo, livres entre si, vilosos. Brácteas involucrais castanhas, triangulares, 5-11 × 2-6 mm, ápice agudo, internas e externas do mesmo tamanho, não ultrapassando a altura das flores, vilosas na face abaxial, pubescentes a pilosas na face adaxial. Capítulos alvos, 5-18 mm diâm. Brácteas florais hialinas, lanceoladas, $4 \times 0,5 \mathrm{~mm}$, ápice agudo a acuminado, ciliada, membranosa. Flores 3-meras; ca. 114 por capítulo, 2 vezes mais estaminadas que pistiladas; flores estaminadas $4 \times 2 \mathrm{~mm}$; pedicelo $1,2 \mathrm{~mm}$ de compr.; sépalas com $3 \times 0,5 \mathrm{~mm}$, elípticas a oblanceoladas, hialinas, com pubescência em tufos na porção apical, tricomas curtos; corola hialina, 3,5 × $1 \mathrm{~mm}$; pilosa no interior do tubo, estames $3 \mathrm{~mm}$ compr., livres das pétalas, anteras 
bitecas, tetraesporangiadas, hialinas, pistilódios 0,4 mm compr.; flores pistiladas 4-6 × 1,5-2 mm; sésseis; sépalas 3,5-5 × 0,8-1 mm, obovadas, hialinas, com tricomas no ápice; pétalas 3-4,5 $\times$ 1,5 mm, lanceoladas, com tricomas nas margens e no ápice; ramos estigmáticos bífidos; apêndices (3) nectaríferos, 1,5 mm compr.; estaminódios 3, escamiformes, 0,3 $\mathrm{mm}$ compr.

Paepalanthus subfalcatus é identificada pelo caule curto restrito à roseta, folhas largamente lanceoladas, pilosas em ambas as faces, e pelas brácteas involucrais castanhas e vilosas. Essas características permitem distinguir a espécie das demais do gênero dentro da área de estudo, mas é semelhante a diversas outras de Paepalanthus compondo um complexo de espécies que não foi possível elucidar neste estudo pelas mesmas razões mencionadas anteriormente para Paepalanthus pedunculatus. Ocorre na Cadeia do Espinhaço em Minas Gerais e devido as poucas amostras da espécie, não é possível inferir a época de floração. Material examinado selecionado: BRASIL. MINAS GERAIS: Diamantina, Parque Estadual do Biribiri, Barro Preto, 17.V.2011, C.O. Andrino 123 (DIAM); Caminho para a Lapa do Forno, 16.XI.2010, C.O. Andrino 87 (DIAM).

30. Paepalanthus trichopetalus Koern. in Mart., Fl. bras. 3(1): 399. 1863.

Erva, 24-30 cm alt., caule aéreo curto, restrito a roseta, até $4 \mathrm{~cm}$ diâm. Folhas planas, persistentes, espiraladas, $10-23 \times 0,5-1,6 \mathrm{~cm}$, lanceoladas, agudas, pubescentes na face abaxial, glabras na face adaxial. Eixo reprodutivo ausente. Espatas 5-6,5 cm compr., pubescentes a glabras, ápice arredondado, margem inteira. Escapos verdes, 15-22 cm compr., conjunto de escapos 5-10 por indíviduo, unidos entre si, 3-9 capítulos por escapo, pubescentes. Brácteas involucrais castanhas, ovadas a triangulares, $2-4 \times 2 \mathrm{~mm}$, ápice agudo a acuminado, as interiores um pouco mais escuras, as internas mais longas que as externas, não ultrapassando a altura das flores, pubescentes em ambas as faces. Capítulos alvos, 6-9 mm diâm. Brácteas florais hialinas, lanceoladas, $3 \times 1,5 \mathrm{~mm}$, ápice agudo a acuminado, ciliada, membranácea. Flores 3-meras; ca. 54 por capítulo, 3 vezes mais estaminadas que pistiladas; flores estaminadas 4 $\times 1 \mathrm{~mm}$; pedicelo $1,5 \mathrm{~mm}$ compr.; sépalas com 3 $\times 0,5 \mathrm{~mm}$, obtruladas, hialinas, ápice agudo, com pubescência em tufos na porção apical; corola hialina, $3 \times 1 \mathrm{~mm}$; glabra no interior do tubo, estames 3,5 mm compr., livres das pétalas, anteras bitecas, tetraesporangiadas, hialinas, pistilódios 1 mm compr.; flores pistiladas 2-3 $\times 1 \mathrm{~mm}$; pedicelo $0,5 \mathrm{~mm}$; sépalas $3 \times 1 \mathrm{~mm}$, elípticas, hialinas, com tricomas no ápice; pétalas $3 \times 1 \mathrm{~mm}$, obtruladas, com tricomas nas margens e no ápice; ramos estigmáticos bífidos; apêndices (3) nectaríferos, $1 \mathrm{~mm}$ compr.; estaminódios 3 , escamiformes, 0,3 mm compr.

Paepalanthus trichopetalus pode ser distinguida das demais pelos escapos unidos, e dentre as espécies com essa característica na área de estudo, por possuir escapos unidos apenas parcialmente. A espécie mais semelhante na área de estudo é $P$. villosulus, que não possui espata e os capítulos são mais numerosos, geralmente ultrapassando dez capítulos por escapo. É restrita ao Planalto de Diamantina, com poucas populações conhecidas. Foi coletada no presente estudo em período de chuvas, no mês de janeiro, a beira de estrada de terra, em ambiente de cerrado sensu stricto.

Material examinado: BRASIL. MINAS GERAIS: Diamantina, Parque Estadual do Biribiri, estrada para cachoeira da Sentinela, 14.I.2011, C.O. Andrino \& I.M. Franco 115 (DIAM).

31. Paepalanthus vaginatus Koern. in Mart., Fl. bras. 3(1): 313. $1863 . \quad$ Fig. 4e

Erva, $45-75 \mathrm{~cm}$ alt., caule aéreo curto, restrito à roseta, até $1 \mathrm{~cm}$ diâm. Folhas planas, persistentes, rosuladas, 3-5,5 × 0,4-0,6 cm, lanceoladas, agudas, glabrescentes em ambas as faces. Eixo reprodutivo ausente. Espatas 8-10 cm compr., glabrescentes, ápice agudo, margem inteira. Escapos castanhos a dourados, 40-70 cm compr., conjunto de escapos 4-14 por indíviduo, livres entre si, glabros. Brácteas involucrais marrom-escuras, triangulares a ovadas, 2-4 × 1-2 mm, ápice agudo a obtuso, as internas e externas do mesmo tamanho, não ultrapassando a altura das flores, glabras em ambas as faces, ciliadas no ápice. Capítulos alvos, 6-10 mm diâm. Brácteas florais castanhas, linear a lanceoladas, 1,5 $\times 0,3 \mathrm{~mm}$, ápice truncado, ciliada, membranácea. Flores 2-meras; ca. 180 por capítulo, estaminadas e pistiladas na mesma proporção; flores estaminadas $3 \times 0,5 \mathrm{~mm}$; pedicelo $1 \mathrm{~mm}$ compr.; sépalas com $2 \times 0,5 \mathrm{~mm}$, elípticas a lanceoladas, hialinas, ciliadas no ápice, tricomas curtos; corola hialina, $1,5 \times 1 \mathrm{~mm}$; glabra no interior do tubo, estames $1,5 \mathrm{~mm}$ compr., livres das pétalas, anteras bitecas, tetraesporangiadas, hialinas, pistilódios $0,4 \mathrm{~mm}$ 
compr; flores pistiladas 3-4 × 1, mm; pedicelo $5 \mathrm{~mm}$ compr; sépalas 3-4 × $1 \mathrm{~mm}$, elípticas, creme a marrom-escuras na metade distal, com tricomas no ápice; pétalas $2 \times 0,5 \mathrm{~mm}$, lanceoladas, com tricomas no ápice; ramos estigmáticos bífidos; apêndices (2) nectaríferos, $1 \mathrm{~mm}$ compr.; estaminódios 2, escamiformes, 0,3 mm compr.

Paepalanthus vaginatus possui hábito muito semelhante à maioria das espécies pertencentes a $P$. ser. Paepalanthus, com caule muito curto, restrito à roseta e escapos longos e numerosos. Entretanto, pode ser facilmente reconhecida pelas flores dímeras, característica incomum nas espécies desse grupo, e que aloca $P$. vaginatus em $P$. ser. dimeri. A espécie possui ampla distribuição no Espinhaço mineiro (Giulietti et al. 2014). Há registros de coleta de $P$. vaginatus de janeiro a junho.

Material examinado selecionado: BRASIL. MINAS GERAIS: Diamantina, Parque Estadual do Biribiri, Alto da Jacuba, 16.V.2011, C.O. Andrino 156 (DIAM); Lapa do Forno, 19.V.2011, C.O. Andrino 171 (DIAM), caminho para Lapa do Forno, 16.VII.2008, L. Echternacht \& T.V. Bastos 1786 (SPF).

32. Paepalanthus villosulusMart. ex Koern. in Mart., Fl. bras. 3(1): 400. $1863 . \quad$ Fig. 4f

Erva, 32-35 cm alt., caule aéreo curto, restrito à roseta, até $3 \mathrm{~cm}$ diâm. Folhas planas, persistentes, rosuladas, 9,5-30 × 1-1,5 cm, lanceoladas, agudas, pilosas em ambas as faces. Eixo reprodutivo ausente. Espatas ausentes. Escapos verdes, 23-25 cm compr., conjunto de escapos 10-30 por indíviduo, parcialmente unidos, 16-24 capítulos por escapo, glabrescentes. Brácteas involucrais castanho-escuras, ovadas, $3 \times 1,5 \mathrm{~mm}$, ápice cuspidado, as internas mais longas que as externas, não ultrapassando a altura das flores, face abaxial pilosa a pubescente. Capítulos alvos, 5-7 mm diâm. Brácteas florais hialinas, com pigmentação granular na porção distal, obovadas, 2,5-3 × $1 \mathrm{~mm}$, ápice agudo, ciliada, membranácea. Flores 3-meras; ca. 59 por capítulo, 4 vezes mais estaminadas que pistiladas; flores estaminadas $3 \times$ 1-1,5 mm; pedicelo 0,5 mm compr.; sépalas com 2,5 × 1,5 mm, oblanceoladas, castanho-escuras, glabras; corola castanho- escura, $2 \times 1-1,5 \mathrm{~mm}$; glabra, estames $2 \mathrm{~mm}$ compr., livres das pétalas, anteras bitecas, tetraesporangiadas, hialinas, pistilódios incospícuos; flores pistiladas $3 \times 1-1,2$ $\mathrm{mm}$; sésseis; sépalas $2,5 \times 1,5 \mathrm{~mm}$, oblongas a ovadas, castanho-escuras na porção distal, glabras, ápice agudo; pétalas 2,5 × 1-1,5 mm, lanceoladas, glabras; ramos estigmáticos bífidos; apêndices
(3) nectaríferos, $1 \mathrm{~mm}$ compr.; estaminódios 3, escamiformes, 0,3 mm compr.

Paepalanthus villosulus ertence a $P$. subg. Platycaulon, portanto possui escapos unidos. Dentro do subgênero, pode ser facilmente reconhecida por apresentar escapos unidos parcialmente, liberando-se nas extremidades, e pela ausência de espatas, característica que é observada somente nesta espécie. Há registros da espécie na Colômbia, Venezuela, Peru e no Brasil, apresenta uma distribuição disjunta, ocorrendo nos estados do Paraná e Minas Gerais (Tissot-Squali 1997). Em Minas Gerais foi coletada em Diamantina, Congonhas do Norte e Ouro Preto. Não havia registros dessa espécie no PEBI até o presente tratamento. Foi encontrada em solo arenoso de campo rupestre, em uma população com poucos indivíduos a leste do Parque. Há registros de coleta de $P$. villosulus em todos os meses do ano, e no presente estudo, foi coletada em maio, com capítulos no final da antese.

Material examinado: BRASIL. MINAS GERAIS: Diamantina, Parque Estadual do Biribiri, Alto da Jacuba, 16.V.2011, C.O. Andrino 155 (DIAM).

33. Paepalanthus xanthopus Silveira, Floral. Mont.: 70. 1928.

Fig. $4 \mathrm{~g}, \mathrm{~h}$

Erva, 42-52 cm alt., caule aéreo curto, restrito à roseta, até $2 \mathrm{~cm}$ diâm, crescimento cespitoso. Folhas planas, persistentes, rosuladas, 5-11 × 2-6 cm, lanceoladas, agudas, pilosas em ambas as faces. Eixo reprodutivo ausente. Espatas 7-15 cm compr., pilosas a pubescentes, ápice agudo, margem inteira. Escapos verdes, 15-50 cm compr., conjunto de escapos 5-22 por indíviduo, livres entre si, pilosos a pubescentes. Brácteas involucrais verde a castanhas, linear a triangulares, 5-12 × 1-2 mm, ápice agudo, as interiores um pouco mais claras, as externas mais longas que as internas, apenas a série externa ultrapassando a altura das flores em 2-7 mm, pubescentes em ambas as faces. Capítulos cor de ocre, 7-15 mm diâm. Brácteas florais creme, linear a lanceoladas, 3-5 × 0,5 mm, ápice agudo, ciliada, membranácea. Flores 3-meras; ca. 192 por capítulo, 3 vezes mais estaminadas que pistiladas; flores estaminadas $5 \times$ $2 \mathrm{~mm}$; pedicelo $2 \mathrm{~mm}$ compr.; sépalas com $3 \times 0,5$ $\mathrm{mm}$, espatuladas, hialinas, ciliada; corola hialina, $2 \times 1 \mathrm{~mm}$; glabra no interior do tubo, estames 2 $\mathrm{mm}$ compr., livres das pétalas, anteras bitecas, tetraesporangiadas, hialinas, pistilódios $0,5 \mathrm{~mm}$ compr; flores pistiladas 3-4 × 1,5-2 mm; sésseis; 


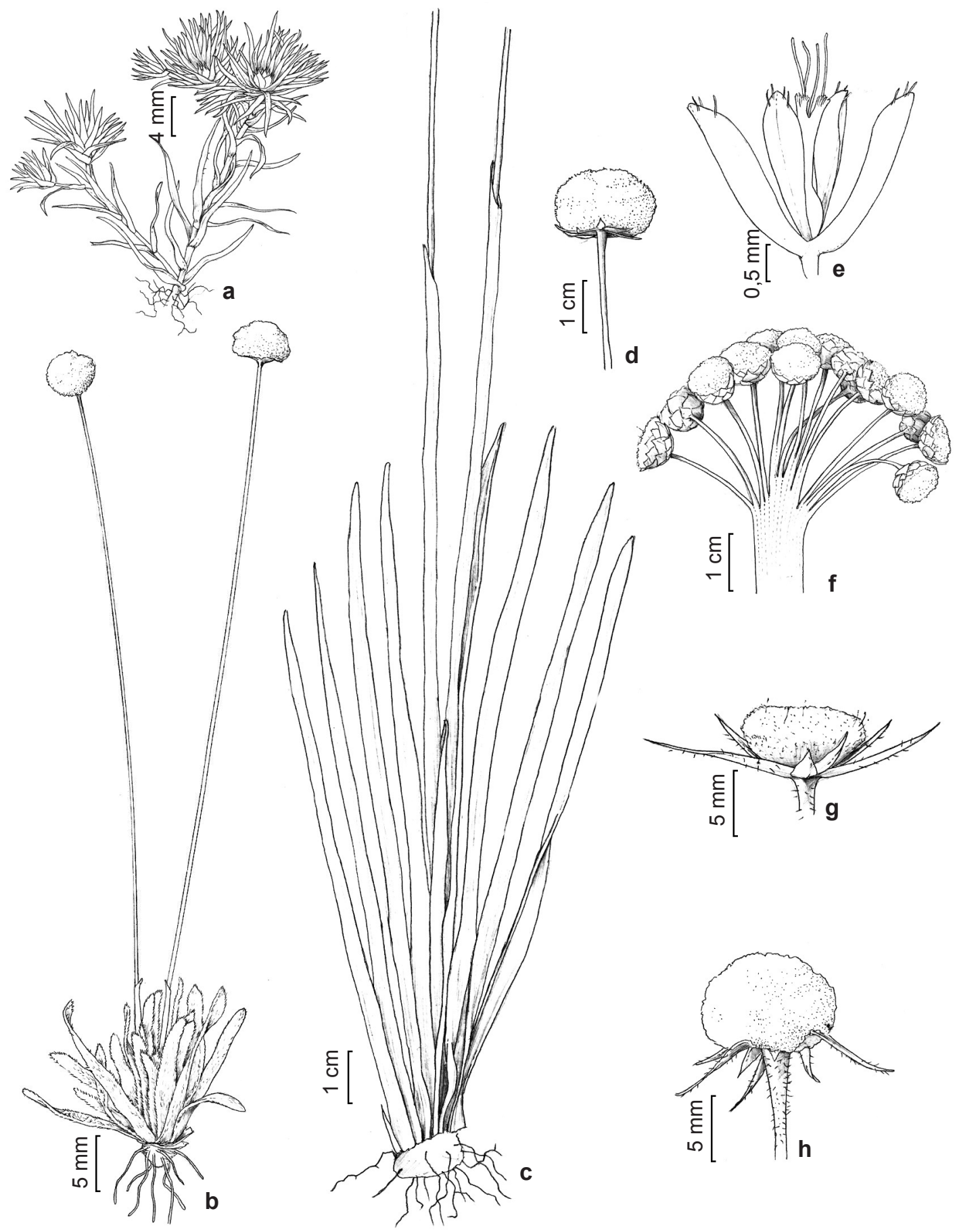

Figura 4 -a. Paepalanthus leucocephalus, hábito; b. P. pubescens, hábito; c-d. Paepalanthus ruficeps - c. filotaxia; d. capítulo; e. P. vaginatus, flor pistilada; f. P. villosulus, capítulos, com escapos parcialmente unidos; g-h. Paepalanthus xantophus, capítulo. (Ilustrado por Marcelo Kubo).

Figure 4 -a. Paepalanthus leucocephalus, habit; b. P. pubescens, habit; c-d. Paepalanthus ruficeps - c. Phillotaxis. d. Capitulum; e. P. vaginatus, pistilatte flower; f. P. villosulus, capitulum, with partial union of scapes; g-h. Paepalanthus xantophus, capitulum. (Line drawing by Marcelo Kubo). 
sépalas $2-4 \times 0,8-1 \mathrm{~mm}$, lineares a lanceoladas, hialinas, com tricomas na margem e no ápice; pétalas 3-4 × 1,5 mm, lanceoladas, com tricomas nas margens e no ápice; ramos estigmáticos bífidos; apêndices (3) nectaríferos, $1 \mathrm{~mm}$ compr.; estaminódios 3, escamiformes 0,2 mm compr.

Paepalanthus xanthopus pode ser reconhecida pelas folhas lanceoladas pubescentes, pelo hábito agregado na maioria das vezes e, principalmente, por três ou mais brácteas da série mais externa ultrapassando a altura das flores no capítulo. Por muito tempo era referida apenas para a Serra do Cabral, no município de Joaquim Felício, localidade tipo da espécie. Com o aumento do esforço amostral na região do Planalto de Diamantina, registrou-se sua ocorrência nos municípios de Gouvêia e Diamantina. No Parque foi coletado em duas localidades, em populações com poucos indivíduos. Floresce de fevereiro a setembro.

Material examinado selecionado: BRASIL. MINAS GERAIS: Diamantina, Parque Estadual do Biribiri, Barris, 26.VII.2011, F.N. Costa et al. 1453 (DIAM); Campo arenoso, próximo ao Morro do Coelho, 16.VII.2008, L. Echternacht \& T.V. Bastos 1789 (SPF).

\section{Agradecimentos}

À Fundação de Amparo à Pesquisa do Estado de São Paulo - FAPESP e a Fundação de Amparo à Pesquisa do Estado de Minas Gerais - FAPEMIG, o auxílio financeiro; ao Rafael Guimarães, a elaboração do mapa; ao Marcelo Kubo, as ilustrações; aos curadores dos herbários citados; à equipe do Instituto Estadual de Florestas, gestores do Parque Estadual do Biribiri, a solicitude e atenção, ao Cleiton Santos Pessoa, Dra. Lívia Echternacht e Dr. José Rubens Pirani, a leitura atenciosa e sugestões e aos dois revisores anônimos, as valiosas contribuições.

\section{Referências}

Andrino, C.O. \& Costa, F.N. 2013. Paepalanthus subgen. Xeractis (Eriocaulaceae) na porção central da Cadeia do Espinhaço em Minas Gerais, Brasil. Rodriguésia 64: 75-89.

Costa, F.N.; Trovó, M. \& Sano, P.T. 2008. Eriocaulaceae na Cadeia do Espinhaço: riqueza, endemismos e ameaças. Megadiversidade 4: 89-97.

Costa, F.N. \& Sano, P.T. 2013. New Circumscription of the Endemic Brazilian Genus Actinocephalus (Eriocaulaceae). Novon 22: 281-287.

Echternacht, L.; Trovó, M.; Costa, F.N. \& Sano, P.T. 2012. Análise comparativa da riqueza de Eriocaulaceae nos Parques Estaduais de Minas Gerais. Vol. 4. MG Biota, Belo Horizonte. Pp. 18-31.

Forzza, R.C.; Baumgratz, J.F.A.; Costa, A.; Hopkins, M.; Leitman, P.M.; Lohmann, L.G.; Martinelli, G.; Morim, M.P.; Coelho, M.A.N.; Peixoto, A.L.; Pirani, J.R.; Queiroz, L.P.; Stehmann, J.R.; Walter, B.M.T. \& Zappi, D. 2010. Angiospermas do Brasil. In: Forzza, R.C., Catálogo de plantas e fungos do Brasil. Vol. 1. Jardim Botânico do Rio de Janeiro, Rio de Janeiro. Pp. 79-89.

Giulietti, A.M. \& Hensold, N. 1990. Padrões de distribuicao geográfica dos gêneros de Eriocaulaceae. Acta Botanica Brasilica 4: 133-158.

Giulietti, A.M.; Menezes, N.L.; Pirani, J.R.; Meguro, M. \& Wanderley, M.G.L. 1987. Flora da Serra do Cipó, Minas Gerais: caracterização e lista das espécies. Boletim de Botânica da Universidade de São Paulo 9:1-152.

Giulietti, A.M.; Sano, P.T.; Costa, F.N.; Parra, L.R.; Echternacht, L.; Tissot-Squali, M.L.; Trovó, M.; Watanabe, M.T.C.; Hensold, N. \& Andrino, C. 2014. Eriocaulaceae. In: Lista de Espécies da Flora do Brasil. Jardim Botânico do Rio de Janeiro. Disponível em $<$ http://floradobrasil.jbrj. gov.br/jabot/floradobrasil/FB110>. Acesso em 18 setembro 2014.

Hensold, N. 1988. Morphology and Systematics of Paepalanthus subgenus Xeractis (Eriocaulaceae). Systematic Botany Monographs 23: 1-150.

Hensold, N. 1998. Flora da Serra do Cipó, Minas Gerais: Paepalanthus subg. Xeractis (Eriocaulaceae). Boletim de Botânica da Universidade de São Paulo 17: 207-218.

IEF - Instituto Estadual de Florestas. 2004. Plano de manejo do Parque Estadual do Biribiri: EMA/IEF. Curitiba. 606p.

Moldenke, H.N. 1937. Paepalanthus herzogii Moldenke. Revista Sudamericana de Botánica 4: 17.

Moldenke, H.N. 1946. Paepalanthus coutoensis Moldenke. Phytologia 2: 140.

Moldenke, H.N. 1951. Eriocaulaceae. In: Steyermark, J. (ed.). Botanical exploration in Venezuela. Fieldiana Botany 28:114-129.

Moldenke, H.N. 1957. Wurdackia gen. nov. In: Maguire, B.; Steyermark, J. \& Wurdack, J.J. (eds.). Botany of the Chimantá Massif. I. Gran Sabana, Venezuela. Memoirs of the New York Botanical Garden 9: 278-283.

Moldenke, H.N. 1966. Notes on new and noteworthy plants XLIII. Phytologia 13: 218.

Moldenke, H.N. 1968. Additional notes on the Eriocaulaceae. XIV. Phytologia 17: 372-395.

Moldenke, H.N. 1971. A fifth summary of the Verbenaceae, Avicenniaceae, Stilbaceae, Dicrastylidaceae, Symphoremaceae, Nyctanthaceae and Eriocaulaceae of the world as to valid taxa, 
geographic distribution and synonymy. Vol. 2 . Braun-Brumfield, Ann Arbor. Pp. 417-419.

Moldenke, H.N. 1978. Paepalanthus brachypus f. brevipilosus Moldenke. Phytologia 40: 261.

Parra, L.R. 1998. Flora da Serra do Cipó, Minas Gerais: Syngonanthus Ruhland (Eriocaulaceae). Boletim de Botânica da Universidade de São Paulo 17: 219-254.

Parra, L.R.; Giulietti, A.M.; Andrade, M.J.G. \& van den Berg, C. 2010. Reestablishment and new circumscription of Comanthera (Eriocaulaceae). Taxon 59: 1135-1146.

Radford, A.E.; Dickison, W. C.; Massey, J. R. \& Bell, C. R. 1974. Vascular plant systematics. Harper \& Row Pub., New York. 891p.

Rosa, M.M. \& Scatena, V.L. 2007. Floral anatomy of Paepalanthoideae (Eriocaulaceae, Poales) and their Nectariferous structures. Annals of Botany 99: 131-139.

Ruhland, W. 1903. Eriocaulaceae. In: Engler, A. (ed.). Das Pflanzenreich. Vol. 4. Wilhelm Engelmann, Leipzig. 294p.

Sano, P. T. 1998. Flora da Serra do Cipó, Minas Gerais: Paepalanthus sect. Actinocephalus - Eriocaulaceae. Boletim de Botânica da Universidade de São Paulo 17: 187-205.

Sano, P.T. 2004. Actinocephalus (Korn.) Sano (Paepalanthus sect. Actinocephalus), a new genus of Eriocaulaceae, and other taxonomic and nomenclatural changes involving Paepalanthus Mart. Taxon 53:99-107.
Sano, P.T.; Trovó, M.; Parra, L.R. \& Müller, G. 2010. Flora de Grão Mogol, Minas Gerais: Eriocaulaceae. Boletim de Botânica da Universidade de São Paulo 28:125-140.

Silveira, A.A. 1908. Flora e serras Mineiras. Imprensa Official, Belo Horizonte. 205p.

Silveira, A.A. 1928. Floralia Montium. Vol 1. Imprensa Official, Belo Horizonte. 426p.

Scatena, V.L.; Oriani, A. \& Sano, P.T. 2008. Morphological architecture of Actinocephalus (Koern.) Sano (Eriocaulaceae-Poales). Flora 203: 341-349.

Thiers, B. [continuously updated]. Index Herbariorum: A global directory of public herbaria and associated staff. New York Botanical Garden's Virtual Herbarium. Disponível em $<$ http://sweetgum.nybg. org/ih/>. Acesso em 21 maio 2014.

Tissot-Squalli, M.L. 1997. Monographische Bearbeitung von Paepalanthus subgenus Platycaulon. Tese de Doutorado. Ruhr Universität Bochum, Bochum. 242p.

Trovó, M.L.O. 2010. Sistemática de Paepalanthoideae (Eriocaulaceae): Filogenia, morfologia e taxonomia de Diphyomene (Ruhland) Trovó. Tese de Doutorado. Universidade de São Paulo, São Paulo. 259p.

Trovó, M. \& Sano, P.T. 2010. Taxonomic survey of Paepalanthus sect. Diphyomene Ruhland (Eriocaulaceae). Phytotaxa 14: 49-55.

Weberling, F. 1989. Morphology of flowers and inflorescences. Cambridge University Press, Cambridge. 188p. 
Lista de Excicatas:

Almeida et al. 1479 - SPF (27); Andrino \& Cota 176 - DIAM (19), 177 - DIAM (9), 180 - DIAM (18); Andrino \& Franco 103 - DIAM (18), 109 - DIAM (12), 112 - DIAM (13), 115 - DIAM (30); Andrino \& Sano 244 - SPF (16); Andrino 6 - DIAM (6), 87 - DIAM (29), 123 - DIAM (29), 154 - DIAM (24), 155 - DIAM (32), 156 - DIAM (31), 158 - DIAM (25), 159 - DIAM (28), 162 - DIAM (14), 163 DIAM (11), 164 - DIAM (1), 166 - DIAM (25), 167 - DIAM (8), 168 - DIAM (26), 169 - DIAM (27), 171 - DIAM (31), 173 - DIAM (18), 230 - SPF (10), 235 - SPF (6); Andrino et al. 108 - DIAM (4), 34 - DIAM (24), 76 - DIAM (19), 77 - DIAM (15), 80 - DIAM (22), 81 - DIAM (3), 84 - DIAM (12), 87 - UFVJM (4), 99 - DIAM (32), 165 - DIAM, SPF (23); Araújo \& Lage 46 - DIAM (21), 49 - DIAM (8), 50 - DIAM (21); Araújo 12 - DIAM (21); Araújo et al. 134 - BHCB (22); Cavalcanti et al. - BHCB (13), CFCR 8574 - SPF (13), CFCR 8574 - SPF, BHCB (13); Costa \& Lessa 907 - DIAM (6); Costa \& Sano 262 - SPF (9), 267 - SPF (25), 270 - SPF (18), 272 - SPF (13); Costa 404 - DIAM (1), 675 - DIAM (8); Costa et al. 3 - DIAM (13), 23 - DIAM (27), 55 - SPF (18), 58 - SPF (15), 71 - SPF (15), 197 - SPF (4), 670 - SPF (21), 796 - SPF (18), 1147 - DIAM (22), 1167 - DIAM (1), 1175 - DIAM (1), 1207 - DIAM (12), 1214 - DIAM (19), 1216 - DIAM (8), 1227 - DIAM (22), 1235 - DIAM (31), 1248 - DIAM (31), 1253 - DIAM (3), 1268 - DIAM (1), 1296 - DIAM (11), 1334 - DIAM (27), 1376 - DIAM (22), 1383 - DIAM (32), 1394 - DIAM (1), 1398 - DIAM (1), 1415 - DIAM (11), 1418 - DIAM (1), 1436 - DIAM (31), 1453 - DIAM (33), 1456 - DIAM (8), 1458 - DIAM (22), 1478 - DIAM (1), 1481 - DIAM (13); Echternacht \& Bastos 1776 - SPF (7), 1785 - SPF (13), 1786 - SPF (31), 1788 - SPF (25), 1789 - SPF (33), 1798 - SPF (28), 1804 - SPF (8), 1809 - SPF (20), 1810 - SPF (9), 1816 - BHCB (20), 1817 - SPF (33), 1818 - SPF (18), 1822 - SPF (5), 1828 - SPF (17), 1831 - SPF (3); Echternacht et al. 1712 - SPF (23), 1793 - SPF (18); Egler 17 - RB (32); Ferreira 906 - RB (8); Forzza, 4874 - RB (8); Franco \& Cota 759 - DIAM (26), 867 - DIAM (8); Gibbs et al. 5176 - MBM (9); Giulietti \& Wanderley CFCR 7798 - SPF (5); Giulietti 934-80 - SPF (11), 975-80 - MBM (22), 976 - SPF (32), 981-80 CFCR 69 - SPF (9); Giulietti et al. CFCR 1761 - SPF (4), CFCR 1778 - SPF (21), CFCR 4290 - SPF (17), CFCR 4435 - MBM (8), CFCR 4700 - SPF (11), CFCR 9984 - SPF (8); Hatschbach 1218 - MBM (27), 27372 - UB (13), 30189 - MBM (19), 36485 - MBM (27), 40838 - MBM (3), 40862 - MBM (12), 73551 - MBM (31), 80043 - MBM (11); Hatschbach et al. 29028 - MBM (2), 36492 - MBM (19), 51087 - MBM (31); Hensold 204 - SPF (12), 236 - SPF (9), 263 - SPF (12), 287 - SPF (18), 338 - SPF (4), 339 - SPF (4), 517 - SPF (4), 618 - SPF (5), 619 - SPF (5), 621 - SPF (20), 622 - SPF (18), 630 - SPF (28), 683 - SPF (3), 685 - SPF (13), 686 - SPF (9); Hensold et al. CFCR 2659 - SPF (12), CFCR 3108 - SPF (5), CFCR 3134 - SPF (9), CFCR 3165 - SPF (15), CFCR 3166 - SPF (20), CFCR 3172 - SPF (20), s.n. - SPF (29); Horák s.n. - DIAM (10); Irwin 22303 - UB (8); Irwin et al. 22694 - RB (8); Irwin et al. 28578 - UB (8); Isejima et al. CFCR 3592 - SPF (11), CFCR 5539 - SPF (18), CFCR 5544 - SPF (12), CFCR 5551 - SPF (15), CFCR 5631 - SPF (9), CFCR 5634 - SPF (9), CFCR 5637 - SPF (9); Krieger 14026 - MBM (2); Lombardi 4238 - BHCB (13), 4308 - BHCB (4); Magalhaes 536 - BHCB (7), 18364 - UB (23); Martinelli 5946 -RB (1), 6288 - RB (21); Mello-Barreto 10129 - BHCB (8); Mello-Silva et al. 312 - SPF (14), 349 - SPF (20), 352 - SPF (18), 354 - SPF (19), 367 - SPF (4), 1142 - SPF (14), CFCR 7927 - SPF (14); Nunes \& Costa 21 - DIAM (13); Pangaio et al. 721 - SPF (31); Pirani \& Mello-Silva CFCR 11080 - SPF (13); Pirani et al. CFCR 11100 - SPF (4), CFCR 11111 - SPF (21); Sakuragi et al. CFCR 13969 - SPF (4); Sano et al. 676 - SPF (32), 681 - SPF (4), 685 - SPF (12), 812 - SPF (4), 921 - SPF (32), 1012 - SPF (4); Scatena et al. CFCR 10584 - SPF (14), CFCR 10682 - SPF (25); Schwacke 8476 - BHCB (9); Shepherd et al. 3856 - MBM (3); Silva et al. 19 - DIAM (5), 20 - DIAM (2), 21 - DIAM (5), 29 - DIAM (8); Silveira 532 - R (3), 695 - R (26), 827 - R (1); Souza et al. 11945 - SPF (29), 25329 - SPF (13), 28516 - SPF (5); Splett 366 - UB (3), 508 - SPF (20), 562 - SPF (20), 910 - UB (3), 950 - BHCB (3); Stehmann 2798 - BHCB (10); Stützel et al. 19 - SPF (14), 21 - SPF (3), 38 - SPF (31), 61 - SPF (32); Tannure et al. 24 - DIAM (22); Trovó \& Watanabe 348 - SPF (14), 350 - SPF (11), 351- SPF (9), 353 - SPF (31), 371 - SPF (1), 377 - SPF (24); Trovó et al. 427 - SPF (11); Wanderley \& Sajo CFCR 7740 - SPF (9); Williams 8144 - R (9). 